\title{
Effect of particle shape on the mechanical behavior of natural sands
}

\author{
Altuhafi, Fatin N., Ph.D. (corresponding author) \\ Research Associate, \\ Earth Sciences, University College London \\ Email: f.altuhafi@ucl.ac.uk
}

Coop, Matthew R., Ph.D.

Professor of Geotechnical Engineering,

Department of Architecture and Civil Engineering, City University of Hong Kong

Georgiannou, Vasiliki N., Ph.D.

Associate Professor,

National Technical University of Athens

\begin{abstract}
A database of the mechanical behavior of 25 natural sands was compiled from the existing literature. Particle shape and size analysis, obtained by Dynamic Imaging Analysis, for each material in the database has subsequently been linked to its mechanical properties; selected sands were also subject to interferometry study for particle surface roughness measurements. This paper reviews the effect of the particle shape properties of these sands on their Critical State and stiffness parameters, introducing a new parameter to optimize the correlations.
\end{abstract}

Key words: Sand, particle shape, Dynamic Imaging Analysis, angularity, Critical State, Stiffness. 
Symbols:

$\lambda \quad$ Critical State Line gradient in the e - lnp' plane.

$\mathrm{e}_{\Gamma} \quad$ Critical State Line intercept with void ratio axis at $\mathrm{p}^{\prime}=1 \mathrm{kPa}$.

$\phi^{\prime} \mathrm{CS} \quad$ Effective angle of internal friction at critical state.

A Cross-sectional area of particle in 2D projection.

AR Aspect ratio.

$\mathrm{C}_{\mathrm{u}} \quad$ Coefficient of uniformity.

$\mathrm{C}_{\mathrm{x}} \quad$ Convexity.

$\mathrm{C}_{\mathrm{g}} \quad$ Stiffness coefficient.

$D_{R} \quad$ Reference particle size $(2000 \mu \mathrm{m}$ in this study).

$\mathrm{D}_{50} \quad$ Mean diameter.

e Void ratio.

$\mathrm{e}_{\mathrm{c}} \quad$ e at critical state.

e Intrinsic property of sand used to normalize stiffness values for different void ratios.

$\mathrm{e}_{\max } \quad$ Maximum e of particle assembly in a sample.

$\mathrm{e}_{\min } \quad$ Minimum e of particle assembly in a sample.

$f(e)$ Void ratio function used to normalise stiffness of soils.

$\mathrm{G}_{0} \quad$ Elastic shear modulus.

$G_{0}^{\prime 100} \quad$ Normalised elastic stiffness at $\mathrm{p}^{\prime}=100 \mathrm{kPa}$.

L Perimeter of particle in 2D projection.

n Elastic stiffness exponent.

p' Mean normal effective stress.

$\mathrm{p}_{\mathrm{a}} \quad$ Elastic stiffness reference pressure.

$\mathrm{p}_{\mathrm{c}}^{\prime} \quad \mathrm{p}^{\prime}$ at critical state.

S Sphericity.

$\mathrm{S}_{\mathrm{a}}, \mathrm{S}_{\mathrm{q}} \quad$ Surface roughness factors.

SAGI Shape-Angularity Group Indicator.

R Roundness.

RMD Relative mean diameter. 


\section{Introduction}

The formation history of natural sand grains usually stamps the sand particles with certain characteristics which reflect the mechanical and chemical processes involved in their formation. The composition of sedimentary sandy soils varies, depending on the local sources of detrital materials and the depositional conditions. Weathered soils usually have mixed mineralogy and grading because they are not sorted by transportation. Silica, usually in the form of quartz, is the sand mineral most common constituent and the most resistant to crushing. The second most common mineral, calcium carbonate, is encountered in many marine sands of biogenic origins resulting from various forms of sea life, like corals or animal shells.

Alluvial and beach quarzitic soils become progressively rounder with transportation, while some weak particle soils, such as volcanic ashes may show higher angularity due to breakage during transportation. However, excessive shearing of weak soils during transportation might also lead to particle abrasion and reduction in particle size, resulting in well graded less angular particles, as in the case of subglacial sediments investigated by Altuhafi \& Baudet (2011).

In the civil engineering literature the mechanical behavior of natural sands is related to their micro-characteristics and particle morphology. Moreover, the variation of packing ability, compression properties, yielding and stiffness parameters are interpreted as a function of absolute particle size and variability of grading, as well as their particle micro-characteristics (e.g.: Santamarina \& Cascante, 1998; Cho et al., 2006; Cavarretta et al., 2010; Georgiannou, 2011, Otsubo et al., 2015). 
Although a fundamental understanding has been established regarding the role of particle properties on sand behavior, their impact is poorly quantified through measurable indices. Based on a database of 25 natural sands this study examines the effect of particle shape properties on sand macro-behavior and introduces a new parameter which captures the effect on strength and stiffness.

The particle shape and size properties of the sands have been re-determined by means of a laser imaging system. This technology enables rapid analysis of the particle size and shape of a stream of moving particles. Additionally, some of these sands have also been subjected to particle surface roughness evaluation using an interferometer. The mechanical properties of these soils are reviewed in light of their particle characteristics expressed by specifically defined shape descriptors.

\section{Measurement of Shape descriptors}

Definitions of shape factors have been discussed by many authors (Wadell 1932; Powers 1953; Krumbein \& Sloss 1963; Barrett 1980). While sphericity is a property related to 'form' which is sensitive to particle elongation, roundness relates to angularity which refers to the particle protrusions (Wadell, 1932). Roundness is defined as the ratio of the curvature of the corners and edges to that of the overall particle. Many alternative methods were proposed in the literature such as by considering the corner angle of particle asperities (Lees 1964), or the perimeter of the particle (Kato et al., 2001). Though some authors provide numerical roundness values (e.g. Rouse et al., 2014, Yoshimoto et al., 2012; Tatsuoka et al., 2008), in geotechnical research authors more commonly describe roundness qualitatively. 
A major consideration for any approach of roundness and shape definition is their ease of use and particularly the acceptable representative sample size. Recently, the development of digitized imaging systems using Dynamic Image Analysis (DIA) has facilitated obtaining high resolution laser images of a flow of randomly orientated moving particles, having the advantage of evaluating a large number of particles in a short time. The equipment used in this research was a QicPic (Sympatec, 2008), which can measure particle sizes between $1 \mu \mathrm{m}$ and $20 \mathrm{~mm}$ while taking images at speeds of up to 500 frames/s at different particle image planes. A description of the apparatus has been given in detail by (Altuhafi et al., 2013). A dry gravity feeding system for particles over about $0.05 \mathrm{~mm}$ was used and for those soils with a fines fraction, the fines percentage was measured and removed by sieving, so the particle shape distribution is based on the coarse particles only, making the assumption that the shape of the larger particles is more influential than the shape of the fine particles (Li, 2013).

At a smaller scale level, surface texture reflects more localized features including roughness of the particle surface, roundness of edges and corners and the occurrence of asperities that are superimposed on larger scale shape features. An optical interferometer has been used to convert an optical view of the sample into an elevation map. The vertical resolution of the image depends on the step size used when a series of images is taken at different heights of the microscope stage. To limit acquisition and calculation times, a step size of $15.7 \mathrm{~nm}$ was used in this paper, thus limiting the accuracy of the measurements to one half of this value, around $8 \mathrm{~nm}$.

DIA is based on the digitized images of each individual particle for a vast sample size. Several Feret diameters can be calculated, but it was found that for most soils the Feret minimum gives the closest value to a sieve analysis and so this has been used throughout the current paper to represent size (Altuhafi et al., 2013). It is defined as the minimum distance between two parallel lines which touch the particle on opposite sides 
in a 2D image. The aspect ratio (AR) is the ratio between Feret minimum and Feret maximum diameters, while sphericity (S) is calculated as the ratio of the perimeter of the equivalent circle with the same area as the particle, to the actual perimeter. This definition is effectively equal to the square root of circularity as defined by the International Standard ISO/DIS (2006) (Cavarretta et al., 2010). Although it is not the same value or definition it correlates well with the sphericity values in the Krumbein \& Sloss (1963) visual identification chart as well as those in the chart proposed by Powers (1953) (Altuhafi et al., 2013). Convexity, $C_{x}$, describes the compactness of a particle and is calculated as the ratio of the projected particle area to the gross area including any re-entrant sections. Particle size or shape distributions are based on volume in keeping with the normal soil mechanics practice of using sieved weights.

The calculations of the surface roughness parameters were made for a selected surface or cut section of 20 by $20 \mu \mathrm{m}$ in this study. The parameters considered for surface roughness are $S_{a}$, which is the arithmetic mean of the absolute values of deviation from the mean height value, and $\mathrm{S}_{\mathrm{q}}$, which is the square root of the arithmetic mean of squared deviations from the mean height (Sacerdotti et al., 2000). To avoid either particle size or shape influencing the values, both $\mathrm{S}_{\mathrm{a}}$ and $\mathrm{S}_{\mathrm{q}}$ are calculated relative to a smoothed surface rather than a flat plane by specifying the size of shape motifs for the designated areas; a value of $5.02 \mu \mathrm{m}$ was used in this study.

\section{The database of natural sands}

A database of 25 Natural sands has been compiled to evaluate the effect of size, shape and mineralogy on the mechanical behavior of sands. Most of these sands have been extensively studied and their behavior is well established in the literature. It is important to note here that some of these 
sands are quarried sands produced with a certain grading, which might be significantly different to their natural depositional grading; however, their shape and texture may still have an imprint of their depositional history if they were not subjected to selective crushing during the mining process. Quarried sands are highlighted in the database by an underlined font. Table 1, summarizes the mechanical behavior of these sands as well as some geological and mineralogical data reported in the literature. Table 2 shows the size and shape factors determined by DIA. Surface roughness measurement evaluations for some of these sands are also shown in this table, based on the mean value measured for ten particles.

Most of the sands have a predominantly silica (quartz) mineralogy, but some other mineralogies are included for comparison. These mineralogies are: carbonate sands (Dogs Bay Sand and Chiibishi), decomposed granite (Massadu) and volcanic or basaltic sands (Shirasu and Langjökull). Additionally, some non-soil materials are included such as intact and crushed glass beads (ballotini); in the literature these materials have often been employed as an analog soil (e.g. Cavarretta et al., 2010; Cho et al, 2006; Kuwano, 1999; Lesniewska \& Muir Wood, 2011). The sands that have undergone significant diagenesis are indicated, and a few weak sandstones are included which have been tested in a reconstituted i.e. uncemented state.

\section{Critical state parameters}

Continuum mechanics assumes that applied forces are transmitted uniformly through a homogenized granular system, but in reality the interparticle force distributions are strongly heterogeneous, and the loads are transferred through a network of force chains. At lower pressures plastic deformation is associated with the buckling of these chains and energy is dissipated by sliding at the contacts. Particle shape can influence the way 
in which the stresses at the contacts are distributed, and hence can determine how the applied stresses are transmitted through the assembly (Muir Wood 2008, McDowell \& Bolton 1998).

While the initial particle shape and inter-particle friction coefficient may play a significant role during compression and shearing at low pressures, their effects might be expected to be more limited after yielding at higher pressures, which usually involves particle breakage and significant change to particle micro-features (Altuhafi \& Coop, 2010). However, the amount of particle crushing in an assemblage of particles should depend not only on particle strength but also on the distribution of contact forces and arrangement of particles, as influenced by the sizes and shapes of the particles. For example, Hagerty et al. (1993) showed that angular glass beads were more susceptible to breakage than round glass beads, which could be attributed to stress concentrations at the apexes of their asperities. The change of the mechanism by which the soil reaches its Critical State before and after yielding results in a curved or bi-linear critical state line, CSL, in the e:lnp' plane (e.g. Verdugo, 1992). A bilinear expression of the form presented in equation 1 can be used to capture this:

$$
e_{c}=e_{\Gamma}-\lambda \ln p_{c}^{\prime}
$$

where $\mathrm{e}_{\Gamma}$ corresponds to the extrapolated void ratio at $\mathrm{p}^{\prime}=1 \mathrm{kPa}, \lambda$ is the gradient of the CSL and $p_{c}^{\prime}$ is the mean effective stress at the Critical State. In this study, where available, the CSL properties $\left(\lambda \& \mathrm{e}_{\Gamma}\right)$ are quoted for both high and low pressure ranges (Table 1). The angle of shearing resistance at Critical State, $\phi_{\text {cs, }}^{\prime}$, for each material is also given as well as packing parameters, $\mathrm{e}_{\max }$ and $\mathrm{e}_{\min }$.

\section{Shear stiffness of sands}


Previous literature studying the elastic shear modulus, $\mathrm{G}_{0}$ for clean sands suggested that $\mathrm{G}_{0}$ can be expressed by a similar empirical equation irrespective of grain shape and size (Iwasaki \& Tatsuoka, 1977); on the other hand it has been reported that the value of $\mathrm{G}_{0}$ for relatively uniformly graded gravels increases with particle size (Hardin \& Kalinski, 2005). However, shear moduli appear to decrease with an increase in uniformity coefficient or an increase in the content of fine particles (Iwasaki \& Tatsuoka, 1977; Wichtmann \& Triantafylidis, 2009 \& 2014).

It is generally accepted that $\mathrm{G}_{0}$ is a function of the mean effective stress, $\mathrm{p}^{\prime}$, and void ratio, e, and can be expressed by a power function (Wroth \& Houlsby, 1985):

$$
G_{0}=C_{g} \cdot f(e) \cdot\left[\frac{p^{\prime}}{p_{a}}\right]^{n} \cdot p_{a}
$$

where $\mathrm{p}_{\mathrm{a}}$ is a reference pressure used to make $\mathrm{n}$ and $\mathrm{C}_{\mathrm{g}}$ dimensionless. The exponent $n$ might be an indicator of the type of particle contact, which could be dependent on particle shape and roughness (Cascante \& Santamarina, 1996), and thus, it might be a material property which could change from one soil to another depending on particle characteristics. The most frequently applied relationship between void ratio and stiffness dates back to Hardin \& Richart (1963), who proposed a linear dependency between propagation velocity v and void ratio e, from which they derived:

$$
f(e)=\frac{\left(e_{g}-e\right)^{2}}{(1+e)}
$$

where $e_{g}$ is an intrinsic property of the sand which depends mostly on size and shape and can be taken equal to 2.17 for rounded particles and 2.97 for angular. Based on bender element and resonant column measurements of $\mathrm{G}_{0}$ and adopting these values of $\mathrm{e}_{\mathrm{g}}$, Table 3 gives the values of $\mathrm{n}$ and $\mathrm{C}_{\mathrm{g}}$ that could be obtained from a reanalysis of the literature data. 
Another function of the form $f(e)=e^{-x}$ has been proposed by other researchers (Biarez \& Hicher, 1994; Lo-Presti et al., 1997). This form can be justified using the simple Hertzian contact theory for perfect spheres by considering an idealized medium of spheres with identical sizes. The exponent of the void ratio function which provides the best fit for experimental data varies between 1.1 and 1.5 with a mean value of 1.3. This latter value was used by Lo Presti et al. (1997) with an $n$ of 0.45 while an exponent equal to 1 and an $n$ of 0.5 was suggested by Biarez \& Hicher, (1994). In this study a void ratio function with an exponent as proposed by Lo Presti et al. (1997) has been adopted. Table 4 compares the above mentioned relationships applied to selected sands in the database with different grain sizes and shapes. Reasonably high correlations are observed for these soils with a mean coefficient of determination $\mathrm{R}^{2} \geq 0.88$. However, since in the relationship proposed by Hardin \& Richart (1963) the value of $e_{g}$ is highly dependent on particle shape, an arbitrarily chosen value could mask the effect of particle shape on stiffness which is the focal point of this study. At pressures higher than the yielding pressure, a unique stiffness relation with p' is obtained regardless of the initial void ratio (Jovicic \& Coop, 1997).

All the data presented herein refer to reconstituted samples to eliminate any effects of a natural soil structure especially in the diagenetic sands. The values of $\mathrm{G}_{0}$ are first normalized with respect to the void ratio function while the exponent $\mathrm{n}$ and the parameter $\mathrm{C}_{\mathrm{g}}$ are defined from the best fit power relations for the available data. The values of these parameters for a reference pressure $p_{a}=1 \mathrm{kPa}$ are shown in Table 5 . A value of $G_{0} / f(e)$ at $\mathrm{p}^{\prime}=100 \mathrm{kPa}$ is also calculated for each soil and this is denoted $G_{0}^{\prime 100}$.

\section{Shape and angularity}


In their attempt to categorize the size and shape of granular materials using the laser imaging system Altuhafi et al. (2013) found that in the Convexity-Sphericity plane, distinct zones could be identified depending on the material angularity classification. The zones of angularity proposed by Altuhafi et al. have been used here for the preliminary categorization of each soil in Figure 1. Optical microscope images, obtained in this study and from the literature, were used to confirm the category of angularity of these soils.

When examining the location of each angularity group of these soils in the $C_{x}-A R$ plane, a fairly distinct occupation of each angularity descriptor was seen in this plane too, with the angular soils located at the lower left of this plane, while the rounded ones are at the upper right. Combining these two approaches in the 3D AR- $\mathrm{C}_{\mathrm{x}^{-}} \mathrm{S}$ space, as shown in Figure 2, parallel planes can be identified to separate soils according to their angularity group, so that each space between two planes represents a certain category of angularity. Using a vector multiplication method, an equation has been derived to define these parallel planes and the zones between them, which are orthogonal to a vector represented by the equation:

$$
\overrightarrow{A B}=-5.4 i+67.8 j+77.9 k
$$

which can be re-written as:

$$
S A G I=5.4(1-A R)-67.8\left(1-C_{x}\right)-77.9(1-S)
$$

The Shape-Angularity Group Indicator, SAGI number, locates the material in the AR- $\mathrm{C}_{\mathrm{X}}-\mathrm{S}$ space with respect to the separating planes, and the value of SAGI can then be used to identify the angularity group. For a perfect sphere, SAGI will be equal to zero and the number will increase as the particles become more angular. 
The use of $C_{x}, S$ and AR for angularity group identification is merely a matter of convenience, as these factors can be easily obtained from an automated system like that used here, unlike roundness measurements which are time consuming. It can be observed that in Figures $1 \& 2$ the highly angular DBS, which has the highest SAGI value of 18.49, is located at the lower left and the highly rounded Ottawa and Badger sands are at the top right of the figures with SAGI values of 7.0 and 5.5 respectively. The descriptor categories defined by the SAGI number were found to be:

Rounded $\quad$ SAGI $<10.0$

Sub-rounded $\quad 10.0 \leq \mathrm{SAGI}<11.0$

Sub-angular $\quad 11.0 \leq \mathrm{SAGI}<12.0$

Angular $\quad \mathrm{SAGI} \geq 12.0$

The SAGI values presented here only represent the soils included in this study, and may need to be refined as more data are added, but they seem to provide an acceptable way of defining the angularity group of soils and non-soil materials, such as glass beads.

As mentioned earlier, the lack of a unified shape description system might be a significant obstacle in obtaining a useful identification of angularity or roundness for any particulate material. Roundness measurements for sands were obtained by previous researchers using a variety of methods. Yoshimoto et al. (2012) presented some roundness measurements for sands using the Roundness Coefficient, R, defined by Kato et al. (2001): 


$$
R=\frac{L^{2}}{4 \pi A}
$$

where $\mathrm{L}$ is the perimeter measured on plan images of particles arranged in the most stable position and $\mathrm{A}$ is the cross-sectional area. $\mathrm{R}$ is equal to unity for a perfectly spherical particle and increases with increasing particle angularity. Figure 3 shows good agreement between values of R for some soils as calculated by Yoshimoto et al. (2012) and the SAGI number, while Figure 4 shows that SAGI is also compatible with the Roundness factor proposed by Krumbein \& Sloss (1969), as reported by Cho et al. (2006). Finally, similar compatibility is observed with the values of degree of angularity as proposed by Lees (1964) for some soils reported in previous studies (Duttine \& Tatsuoka, 2009), as shown in Figure 5. However, while the SAGI values were calculated from data based on many thousands of particles tested by the laser image analysis, the roundness measurements from all these previous studies were made on a much more limited number of particles (typically between 20-30). Table (6) presents a statistical evaluation of the compatibility of SAGI with these three shape characterization methods.

It is interesting to note that in SAGI, $\mathrm{AR}, \mathrm{C}_{\mathrm{x}}$ and $\mathrm{S}$, are joined to define a fairly unique relationship which can describe the angularity of a material. This might imply that for real sands they are linked and not completely independent, i.e. the geological processes that change the shape affect each of the three parameters in a systematic way.

\section{Results and discussion}

Effect of shape on packing ability 
Packing ability of a soil is a function of particle size distribution and also particle shape. Youd (1972) examined the packing of granular materials with different grading uniformities and different roundnesses and found that the void ratios increase as particles become more angular. The effect of shape on packing ability is examined in Figure 6 which shows that reasonable correlations exist between each of $A R, C_{x}$ and $S$ and the minimum and maximum void ratios, with $\mathrm{R}^{2}$ values ranging between $0.17-0.65$. In general, the void ratio decreases with the increase of these shape factors, which is compatible with previous studies (Cho et al., 2006; Miura et al., 1997; Yoshimura \& Ogawa, 1993). The figure also shows the undisturbed void ratios of the diagenetic soils (Castlegate, Saltwash and Greensand), which are even lower than the minimum void ratios of the other soils as a result of the diagenetic processes they have undergone.

The non-silica soils, which happen to be the most angular soils in the database, are also shown here and their data plot above the trends for the silica sands, exhibiting lower packing ability, except for the sub-angular Langjökull glacial sediment which has a very well graded nature with $\mathrm{C}_{\mathrm{u}}=4.8$, and is not included in the figure. In natural soils, glacial tills and decomposed granites usually have higher coefficients of uniformity due to their geological processes of creation, resulting in more efficient packing. If compared to a quartz material of similar grain size distribution, these materials will tend, however, to have a larger void space due to the irregularity and non-uniformity of their grain shapes. This can be observed when the packing ability of the weathered volcanic ashes of Shirasu $\left(C_{u}=3.59, d_{50}=370 \mu \mathrm{m}\right)$ is compared with that of the angular Aio silica sand which has a similar $D_{50}$ but a more uniform grading $\left(C_{u}=2.74, d_{50}=400 \mu m\right)$. The silica sand shows significantly lower values of $e_{m i n}$ and $e_{m a x}$ $(0.582,0.958)$ compared to the Shirasu volcanic ashes $(1.027,1.551)$. The calcareous sediments (DBS \& Chiibishi) have relatively smaller $\mathrm{C}_{u}$ ( $2.56 \& 2.4$ respectively), but nevertheless these materials have greater void space because they consist of skeletal remains which have complex 
particle shapes and internal voids. It is interesting to note that the scatter of the void ratio data is noticeably lower when considering SAGI with $\mathrm{R}^{2}$ values higher than 0.5 for both $\mathrm{e}_{\min }$ and $\mathrm{e}_{\max }$ (Figure $6 \mathrm{~d}$ ).

\section{Effect of shape on shearing behavior}

Figure 7 shows the effect of shape factors on the angle of internal friction at Critical State $\phi_{\text {cs. }}^{\prime}$ A good correlation can be seen with AR and S $\left(\mathrm{R}^{2}=0.734\right.$ and 0.828 respectively), indicating a lower $\phi^{\prime}$ cs for more spherical particles with high AR. The data obtained for the glass beads is the lowest value of $\phi^{\prime}$ cs while the angular carbonate sands (DBS \& Chiibishi) show the highest values, but they too follow a similar trend. A poorer correlation with convexity $\left(\mathrm{R}^{2}=0.194\right)$ in Figure $7 \mathrm{~b}$, is noticed. Some researchers have also noted an increase of $\phi^{\prime}$ cs with more elongated (lower aspect ratio), less convex particles (Li, 2013).

When considering the CSL properties in the e:In $p^{\prime}$ plane in the low pressure range (Figures $8 \& 9$ ), the effect of any of the shape parameters seems to be less clear for $\lambda_{\mathrm{L}}$. Perhaps there is some effect of AR for the silica sands (Figure 8a), which may indicate that soils with lower AR show a CSL with lower $\lambda_{\mathrm{L}}$, but in general the scatter of the data must mean that other factors dominate this parameter.

The intercept of the CSL in the low pressure range, $e_{\Gamma}$, is affected by the packing ability and consequently a clearer effect can be noted in Figure 9. Soils with higher values of $\mathrm{S}, \mathrm{C}_{\mathrm{x}}$ and $\mathrm{AR}$ and thus rounder particles exhibit lower $e_{\Gamma}$, for example the Ottawa and Badger sands. The highest values can be seen for the highly angular soils, such as DBS and Chiibishi. It is interesting that while SAGI that combines all three shape 
parameters, is again the best fit for $e_{\Gamma}\left(\mathrm{R}^{2}=0.404\right)$, which is a packing related parameter, for $\phi^{\prime}$ cs it is not as good as AR or S, because it includes convexity which has a much weaker correlation with $\phi^{\prime}$ cs.

As discussed earlier, the effect of initial particle shape on the CSL properties in the higher pressure range is very limited since the mechanisms change to being dominated by particle damage which involves significant change to particle characteristics. The relevant data are shown in Table 1 but are not plotted as there is no correlation.

\section{Effect of surface roughness on packing and CSL of soils}

Unfortunately the data are insufficient to be able to separate out shape and roughness influences by, for example, plotting the effect of roughness for particles of similar shape and in Figure 10 it can be seen that there is a correlation between the roughness and shape, i.e. the rougher particles are also the most angular. The correlations between roughness and packing, $\phi^{\prime} \mathrm{cs}, \lambda_{\mathrm{L}}$ and $e_{\Gamma}$ in Figure 11 are therefore exactly what might be expected for the influence of shape for SAGI values of the particles for which roughness could be measured, which were generally between about 10-13. It is interesting that there is no clear effect of roughness on $\phi_{\mathrm{cs}}^{\prime}$, apart from that arising from shape. While inter-particle friction may be related to particle roughness (Cavarretta et al., 2010), as Mitchell \& Soga (2005) highlight, the role of inter-particle friction in determining $\phi^{\prime}$ cs is strictly secondary, as its main function is in maintaining stability of the strong force chains.

By comparing the $e_{\Gamma}$ values exhibited by FBS and Toyoura sand, which have fairly similar gradings (both, $\mathrm{D}_{50}=246 \mathrm{~nm}$ and $\left.\mathrm{C}_{\mathrm{u}}=1.37\right)$, it seems that FBS shows a higher $e_{\Gamma}$ value $\left(e_{\Gamma}=1.02\right)$, compared to the $e_{\Gamma}$ value exhibited by Toyoura sand $\left(e_{\Gamma}=0.94\right)$. Considering the fact that 
Toyoura sand has significantly rougher particles than FBS ( $\mathrm{Sa}=230 \mathrm{~nm} \& 111 \mathrm{~nm}$ respectively) this might be attributed to the effect of particle shape as FBS has slightly less spherical, less convex and with lower aspect ratio particles compared to Toyoura sand.

\section{Effect of particle shape and roughness on shearing stiffness of soils}

Since it is well established that the elastic stiffness $\mathrm{G}_{0}$ is affected by void ratio, the data have first to be normalized using a suitable void ratio function, as discussed earlier. However, the void ratio is not the only variable affecting the $\mathrm{G}_{0}$ of soils. Previous research has shown that shear modulus usually decreases with an increase of the coefficient of uniformity and/or the fines content of a sand (Iwasaki \& Tatsuoka 1977; Salgado et al., 2000; Wichtman \& Triantafyllidis, 2014). Particle size was also found to affect soil stiffness (Meng \& Stokoe, 2003). For an effective comparison of the data, a suitable normalizing method for grading and size should also therefore be used. Although the fact that the relationships between both $D_{50}$ and $C_{u}$ with $G_{0}$ were found to be non-linear, for a simplified approach, a linear relationship was assumed:

$$
G_{0} \alpha \frac{D_{50}}{C_{u}}
$$

and a simple normalizing method for size and grading is proposed in this study by introducing the Relative Mean Diameter, RMD:

$$
R M D=D^{50} / D_{R}
$$

where $D_{R}$ is a reference size chosen to make RMD dimensionless. In this study $D_{R}=2000 \mu \mathrm{m}$ was used, i.e. the maximum size of sand particles. The $\mathrm{G}_{0}$ at $100 \mathrm{kPa}$, normalized with respect to the void ratio function $G_{0}^{\prime 100}$ is then multiplied by $\mathrm{C}_{\mathrm{u}}$ and divided by RMD to achieve normalization 
for void ratio, grading represented by $\mathrm{C}_{\mathrm{u}}$, and also RMD. Figure $12 \mathrm{a}$ shows the effect of shape factors on $G_{0}^{\prime 100}$. Reasonable relationships with each of the three shape factors and also SAGI (Figure 12b) can be found. The relationship with convexity appears to be the best, but this is largely the result of the much more limited range of $\mathrm{C}_{\mathrm{x}}$ compared to the other parameters.

The stiffness parameters in Table 5 indicate that the exponent $\mathrm{n}$ for most silica soils ranges between $0.45-0.54$ with higher values for Saltwash and Greensand in their reconstituted states $(0.67 \& 0.62$ respectively). However, there is no strong correlation between any of the shape factors and $n$.

When surface roughness is considered for silica sands in Figure 12c, a possible trend of a slight increase in stiffness with increasing surface roughness can be observed, but this is probably again the effect of shape as stiffness should decrease as roughness increases (Otsubo et al., 2015). The $G_{0}^{\prime 100}$ values for both Toyoura and FBS, which have similar $\mathrm{C}_{\mathrm{u}}$ and particle mean size but distinctly different surface roughness are actually quite similar.

\section{Conclusions}

A survey of shape parameters for a variety of sands has shown that shape parameters generally work well in defining particle packing. A combination of these parameters is expressed through a new parameter introduced in this study SAGI. The fact that SAGI correlates better than each individual parameter ( $\mathrm{S}, \mathrm{C}_{\mathrm{x}}$ and $\mathrm{AR}$ ) both with the packing ability and angularity characteristics of the sand confirms their combined role. In contrast, SAGI works less well for the angle of shearing resistance at critical state because SAGI is heavily affected by convexity, which has no 


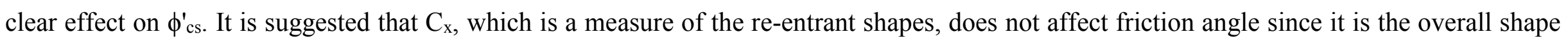
rather than specifically what part is re-entrant that influences $\phi^{\prime}$ cs. In contrast, re-entrant shapes are expected to affect packing. In general, high values of $\phi_{\text {cs }}^{\prime}$ are noted for soils with lower AR particles and the values become lower for more spherical particles.

In the low pressure range, shape affects the intercept of the CSL in the e:lnp' plane, because of the influence that shape has on packing, but not the gradient. Minor particle damage (chipping, asperity damage etc.) as well as particle rearrangement might instead affect the gradient. On the other hand at high stresses shape has very little effect on the CSL location as it is particle strength not shape that controls the location. For natural silica sands, shape correlates reasonably well with the elastic shear modulus. While shape affects most aspects of sand behavior, roughness did not have a clear effect on any parameter, even stiffness.

\section{Acknowledgments}

The authors would like to thank Dr Catherine O’Sullivan of Imperial College London for making the QicPic apparatus available for this research.

\section{References}

Altuhafi, F. \& Baudet, B. (2011). "A hypothesis on the relative role of crushing and abrasion in the mechanical genesis of a glacial sediment".

Eng. Geol. 120, pp1-9. 
Altuhafi, F.N., Baudet, B. \& Sammonds, P. (2010). "The mechanics of subglacial sediment: an example of new transitional behavior". Canadian Geotech. J., 47, 775-790.

Altuhafi, F.N. \& Coop, M.R. (2010). "Changes to particle characteristics associated with the compression of sands". Géotechnique, 61(6), $459-471$.

Altuhafi, F., O’Sullivan, C. \& Cavarretta, I. (2013). “Analysis of an Image-Based Method to Quantify the Size and Shape of Sand Particles". J. of Geotechnical \& Geoenviron. Eng., 139(8), 1290-1307.

Alvarado, G. (2007). "Influence of late cementation on the behaviour of reservoir sands". PhD thesis, Imperial College London.

Alvarado, G., Lui, N., \& Coop, M.R. (2012) "Effect of fabric on the behavior of reservoir sandstones”. Canadian Geotech. J., 49(9), 10361051.

Amat, A. S. (2007). "Elastic stiffness moduli of Hostun sand". MSc thesis. Department of Civil Engineering, University of Bristol.

Barret, P. J. (1980). “The shape of rocks particles, a critical review” Sedimentology, 27, 291-303.

Barton, M. E. \& Palmer, S. N. (1989). “The relative density of geologically aged, British fine and fine-medium sands”. Q. J. Eng. Geol., 22, $49-58$.

Bellotti, R., Jamiolkowski, M., Presti, D.C.F. \& O’Neill, D.A. (1996). “Anisotropy of small strain stiffness in Ticino sand”. Géotechnique, $46(1), 115-131$.

Biarez, J. \& Hicher, P.Y. (1994). "Elementary mechanics of soil behaviour - saturated and remolded soils”, Balkema. 
Bolton, M. D. (1986). “The strength and dilatancy of sands”. Géotechnique, 36 (1), 65-78.

Carrera, A., Coop, M.R. \& Lancellotta, R. (2011). “Influence of grading on the mechanical behaviour of Stava tailings”. Géotechnique, 61(11), 935-946.

Cascante, G., \& Santamarina, J.C. (1996). “Inter-particle contact behavior and wave propagation”. J. Geotech. Eng., 122(10), 831-839.

Cavarretta, I. (2009) "The influence of particle characteristics on the engineering behaviour of granular materials". PhD Thesis, Imperial College, London.

Cavarretta, I., Coop, M. R. \& O'Sullivan, C. (2010). “The influence of particle characteristics on the behaviour of coarse grained soils Géotechnique, 60(6), 413-423.

Chillarige, A.V., Robertson, P.K. Morgenstern, N.R. \& Christian, H.A. (1997) "Evaluation of the in situ state of Fraser River sand". Can. Geotech. J., 34, 510-519.

Cho, G., Dodds, J. \& Santamarina, J.C. (2006). "Particle Shape Effects on Packing Density, Stiffness, and Strength: Natural and Crushed Sands". J. of Geotech. \& Geoenviron. Eng., 132(5), 591-602.

Coop, M.R. \& Lee, I.K. (1993). “The behaviour of granular soils at elevated stresses”. In Predictive Soil Mechanics. Proceedings of the Worth Memorial Symposium, G.T. Houlsby \& A.N. Schofield (Eds.), Thomas Telford, London, 186-198.

Consoli, N.C., Casagrande, M. \& Coop, M.R. (2005). "Effect of fiber reinforcement on the isotropic compression behavior of sand". J. of Geotech. Geoenviron. Eng., 131, 1431-1436. 
Cuccovillo, T. \& Coop, M.R. (1997), “The measurement of local axial strains in triaxial testing using LVDTs”, Géotechnique, 47(1), 167171.

Dano, C. \& Hicher, P.Y. (2003). "Behaviour of uncemented sands and grouted sands before peak strength". Soils \& Foundations, 43(4), 1319.

Delfosse-Ribay, E., Djeran-Maigre, I., Cabrillac, R. \& Gouvenot, D. (2004). "Shear modulus and damping ratio of grouted sand". Soil Dynamics \& Earthquake Engineering 24, 461-471.

Duffy J, \& Mindlin, R.D. (1957). “Stress-strain relations and vibrations of granular medium”. J Appl. Mech.; 10, 585-93

Duttine, A. \& Tatsuoka, F. (2009). "Viscous properties of granular materials having different particle shapes in direct shear". Soils \& Foundations, 49(5), 777-796.

Fogale-Nanotech (2005). General User Manual. Version 1.3. Nimes, France.

Georgiannou, V.N. (2011). 'Behavioural patterns of fine sands' Geotechnical Engineering Journal of the SEAGS \& AGSSEA, Vol. 42 No.4, 26-41.

Gibson, A.D. (1996). "Physical scale modelling of geotechnical structures at one-G", PhD thesis, California Institute of Technology, USA.

Hagerty, M.M., Hite, D.R., Ullrich, C.R. \& Hagerty, D.J. (1993). “One-dimensional high pressure compression of granular media”. J. of Geotechnical Eng. 199(1), 1-18.

Hardin, B.O. \& Kalinski, M.E. (2005). "Estimating the shear modulus of gravelly soils”. J. Geotech. Geoenviron. Eng. 131(7), 867-875. 
Hardin, B.O., Richart Jr FE. (1963). "Elastic wave velocities in granular soils”. J. Soil Mech. Found Div., 89(1), 33-66.

Heineck, K.S., Coop, M.R. \& Consoli, N.C. (2005). "Effect of micro-reinforcement of soils from very small to large shear strains". J. Geotech. Geoenviron. Eng., 131(8), 1024-1033

Hicher, P.Y., Dano, C. \& Chang, C.S. (2008). “A microstructural model for cemented sand”. 12 ${ }^{\text {th }}$ Int. Conf. (IACMAG), 1-6 Oct 2008, India, 661-668.

Hira, M. Hashiguchi, K. Ueno, M. \& Okayasu, T. (2006). "Deformation behaviour of Shirasu soil by extended sub-loading surface model. Lowland Technology Int., 8(1), 37-46.

Hyodo, M; Aramaki, N \& Nakata, Y (1999). "Particle crushing and undrained shear behaviour of sand". Proc. 9th International Offshore and Polar Engineering Conference- France. Chung, JS; Matsui, T; Koterayama, W (Eds.), 785-791.

ISO (2006). "Representation of results of particle size analysis". Part 1-6. Part 6: Descriptive and quantitative representation of particle shape and morphology. Draft International Standard ISO/DIS 9276, Geneva.

Iwasaki, T. \& Tatsuoka, F. (1977). "Effects of grain size and grading on dynamic shear moduli of sands”. Soils \& Found. 17, No. 3, 19-35.

Jovicic. V. \& Coop, M.R. (1997) “Stiffness of coarse-grained soils at small strains”. Géotechnique, 47(3), 545-561.

Kato, Y., Nakata, Y., Hyodo, M. \& Murata, H. (2001). "One-dimensional compression properties of crushable soils related to particle characteristics". Geotechnical Engineering, Proc. 14 ${ }^{\text {th }}$ Southeast Asian Conference, K.K.S. Ho and K.S. Li (Eds), 527-532.

Krumbein, W.C. \& Sloss, L.L. (1963). Stratigraphy and Sedimentation $2^{\text {nd }}$ Ed, Freeman and Company, San Francisco. 
Kuwano, R. (1999). “The stiffness and yielding anisotropy of sands”. PhD thesis, Imperial College London.

Lesniewska, D. \& Muir Wood, D. (2011). "Photoelastic and photographic study of a granular material”. Géotechnique, 61(7), 605-611.

Lee, D. M. (1992). “The angles of friction of granular fills”. PhD thesis, Cambridge University.

Lees, G. (1964).” A new method for determining the angularity of particles”. Sedimentology, 3, 2-21.

Li, Y. (2013). "Effects of particle shape and size distribution on the shear strength behavior of composite soils". Bull. Eng. Geol. Environ, 72, 371-381.

Lo Presti, D.C.F., Jamiolkowski, M., Pallara, O., Cavallararo, A. \& Pedroni, S. (1997), “Shear modulus and damping of soils". Géotechnique, 47(3), 603-617.

McDowell, G. \& Bolton, M. (1998). “On the micromechanics of crushable aggregates”. Géotechnique, 48(5), 667-679.

Meng, F.Y. \& Stokoe, K.H. (2003). "Linear dynamic properties of sandy and gravely soils from large scale resonant column tests". In Deformation Characteristics of Geomaterials, Di Benedetto et al. (Eds.), 63-71.

Mitchell, J.K. \& Soga, K. (2005) Fundamentals of Soil Behavior, 3rd Edition, John Wiley and Sons, 577pp.

Muira, K., Maeda, K., Furukawa, M. \& Toki, S. (1997). "Physical characteristics of sand with different primary properties". Soils \& Foundations, 37(3,) 53-64.

Muir Wood, D. (2008). “Critical state and soil modelling”. In Deformational Characteristics of Geomaterials. S.E. Burns, P.W. Mayne \& J.C. Santamarina (Eds.), Amsterdam, 51-72. 
Nakata, Y., Kato, Y., Hyodo, M., Murata, M. \& Hyde, A.F.L. (1999). "Single particle crushing of the mechanical behavior of sand". In Prefailure Deformation Characteristics of Geomaterials, M. Jamiolkowski, R. Lancellotta \& D. Lo Presti (Eds), 221-228.

Otsubo, M., O'Sullivan, C., Sim, W.W. \& Ibraim, E. (2015) Quantitative assessment of the influence of surface roughness on soil stiffness. Géotechnique, 65(8), 694-700.

Powers, M.C. (1953) “A new roundness scale for sedimentary particles” J. Sedimentary Research 23(2) 117-119.

Rouse, P.C. (2003). "Characterization and modelling of a uniformly graded, well-rounded coarse sand”. MSc thesis, University of Chile.

Rouse, P.C., Fannin, R.J. \& Taiebat, M. (2014). “Sand strength for back-analysis of pull-out tests at large displacement”. Géotechnique, 64(4), $320-324$.

Sacerdotti, F., Griffiths, B., Benati, F. \& Kang, H. (2000). “The variability of functional and amplitude three-dimensional roughness parameters for electron-beam and electro-discharged textured surfaces”. Measmt Sci. Technol. 11(3), 171-177.

Salgado, R., Bandini, P. \& Karim, A. (2000). “Shear strength and stiffness of silty sand”. J. Geotechnical \& Geoenvironmental Eng., 126(5), $451-462$.

Santamarina, J.C., \& Cascante, G. (1998). “Effect of surface roughness on wave propagation parameters.” Géotechnique, 48(1), $129-137$.

Santamarina, J.C. \& Cho, G.C. (2001). "Determination of Critical State Parameters in Sandy Soils—Simple Procedure,” Geotechnical Testing J., 24(2), 185-192.

Schanz, T. \& Venneer. P.A. (1996). “Angles of friction and dilatancy of sand”. Géotechnique, 46(1), 145-151. 
Saxena, S.K. \& Reddy, K.R. (1989). “Dynamic moduli and damping ratios for Monterey No.0 sand by R.C. tests”. Soils \& Foundations, 29(2), $37-51$.

Silva dos Santos, A.P., Consoli, N.C., Heineck, K.S. \& Coop, M.R. (2010). "High-Pressure Isotropic Compression Tests on Fiber-Reinforced Cemented Sand”. J. Geotech. \& Geoenviron. Eng., 136(6), 886-890.

Sympatec (2008). Windox - Operating Instructions Release 5.4.1.0.

Tatsuoka, F. Di Benedetto, H., Enomoto, Kawabe, T.S. \& Kongkitkul, W. (2008), "Various viscosity types of geomaterials in shear and their mathematical expression”. Soils \& Foundations, 48(1), 41-60.

Tsomokos, A. \& Georgiannou, V.N. (2010). "Effect of grain shape and angularity on the undrained response of fine sands". Canadian Geotech. J., 47, 539-551.

Verdugo, R. (1992). The Critical State of sands Discussion. Géotechnique, 42(4), 655-663

Verdugo, R. \& Ishihara, K. (1996), “The steady state of sand soils”, Soils \& Foundations, 36(2), 81-91.

Ventouras, K. \& Coop, M.R. (2009). “On the behaviour of Thanet Sand: an example of an uncemented natural sand”. Géotechnique, 59(9), $727-738$.

Wadell, H.A. (1932). "Volume, shape, and roundness of rock particles". J. Geology, 40, 1074-1106.

Wichtmann, T. \& Triantafyllidis, T. (2009). "Influence of the grain-size distribution curve of quartz sand on the small strain shear modulus Gmax.” J. Geotech. Geoenviron. Eng., 135(10), 1404-1418. 
Wichtmann, T. \& Triantafyllidis. T. (2014). "Stiffness and Damping of Clean Quartz Sand with Various Grain-Size Distribution Curves”. J.

Geotech. Geoenviron. Eng., 140(3), 06013003.

Wroth, C. P. \& Houlsby, G. T. (1985). “Soil mechanics, Property characterization and analysis procedure”. Proc. XI ICSMFE. San Francisco, $1-55$.

Yamamuro, J.A. \& Lade, P.V. (1997). “Static liquefaction of very loose sands”. Canadian Geotechnical Journal; Dec; 34, 6; $905-917$.

Yoshimoto, N., Hyodo, M., Nakata, M., Orense, R., Hongo, T., Ohnaka, A. (2012). "Evaluation of shear strength and mechanical properties of granulated coal ash based on single particle strength”. Soils \& Foundations, 52(2), 321-334.

Yoshimura, Y. \& Ogawa, S. (1993). “A simple quantification method of grain shape of granular materials”. Proc. Japan Society Civil Engineering, No.463, 95-103 (in Japanese).

Youd, T. (1972). "Factors controlling maximum and minimum densities of sands." In Evaluation of relative density and its role in geotechnical projects involving cohesionless soils, E.T. Selig \& R.S. Ladd (Eds.), ASTM special technical publications 523, Los Angeles, 98-112.

Youn, J.U., Choo, Y.W. \& Kim, D.S. (2008). "Measurement of small-strain shear modulus $\mathrm{G}_{\mathrm{max}}$ of dry and saturated sands by bender element, resonant column, and torsional shear tests “.Can. Geotech. J., 45, 1426-1438.

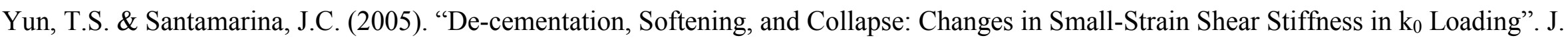
Geotech. Geoenviron. Eng., 131(3), 350-358. 


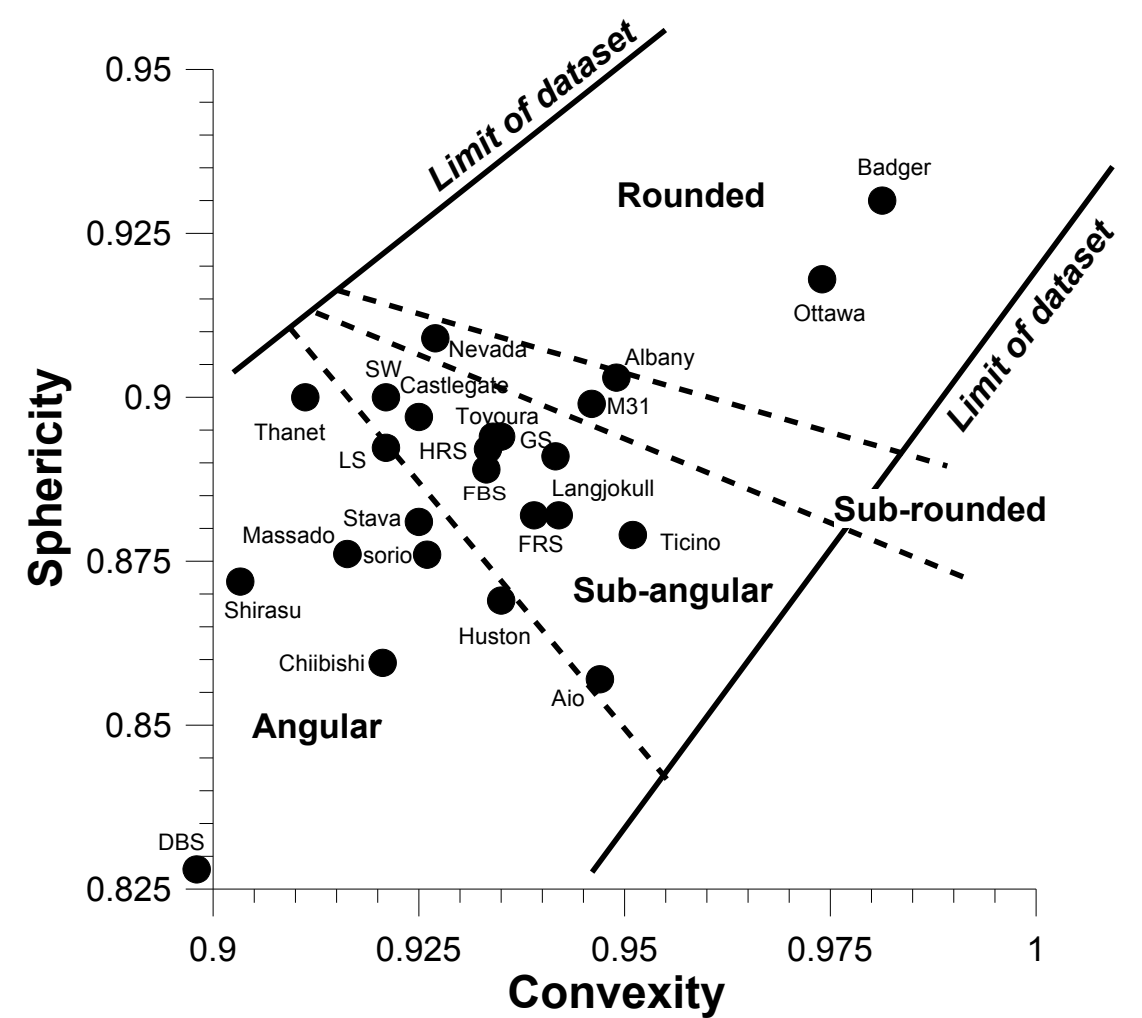

Fig. 1. Angularity zones in the Convexity-Sphericity plane as proposed by Altuhafi et al. (2013). 


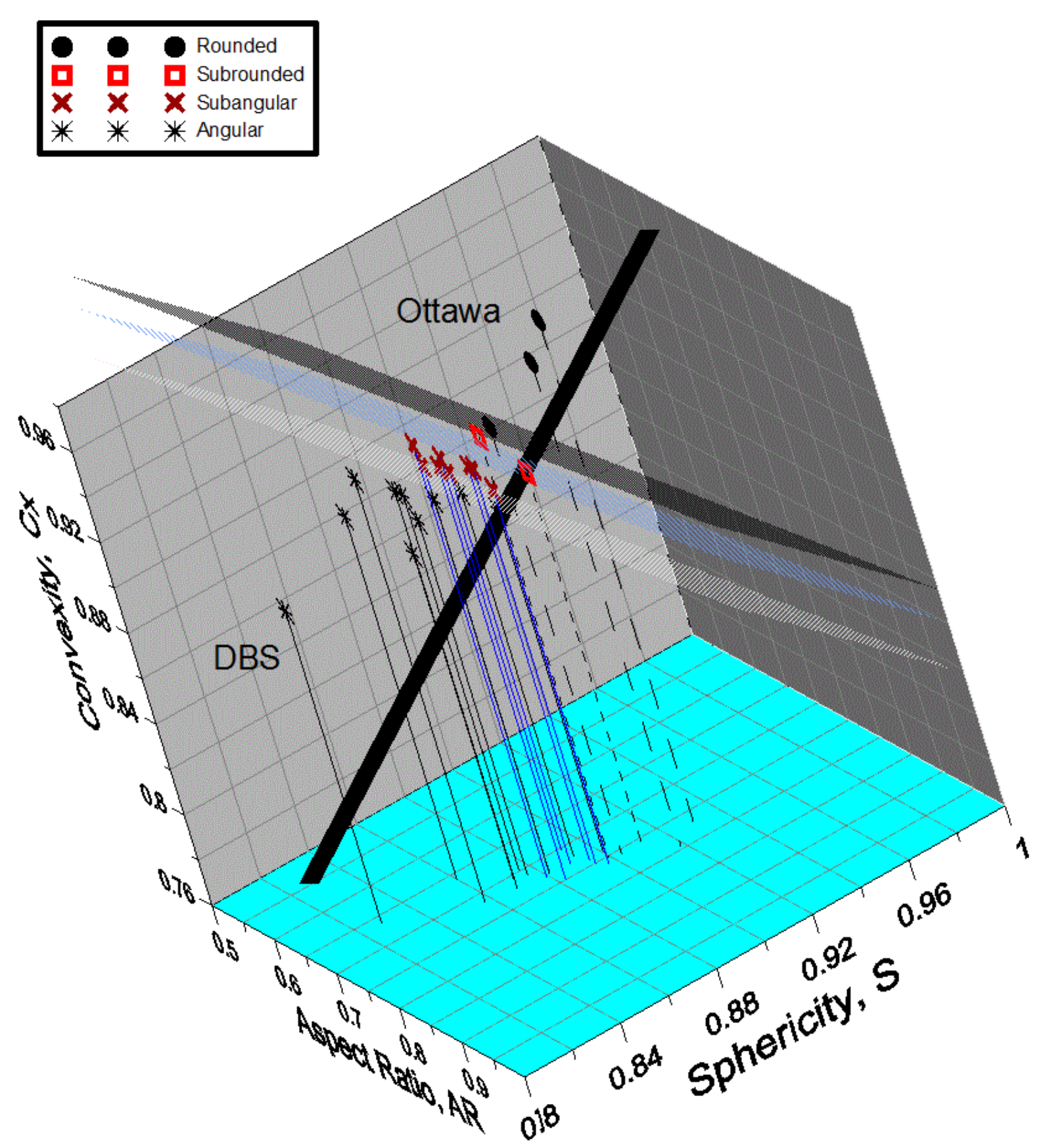


Fig. 2. The soil shape data in AR-Cx-S space separated by angularity boundary planes.

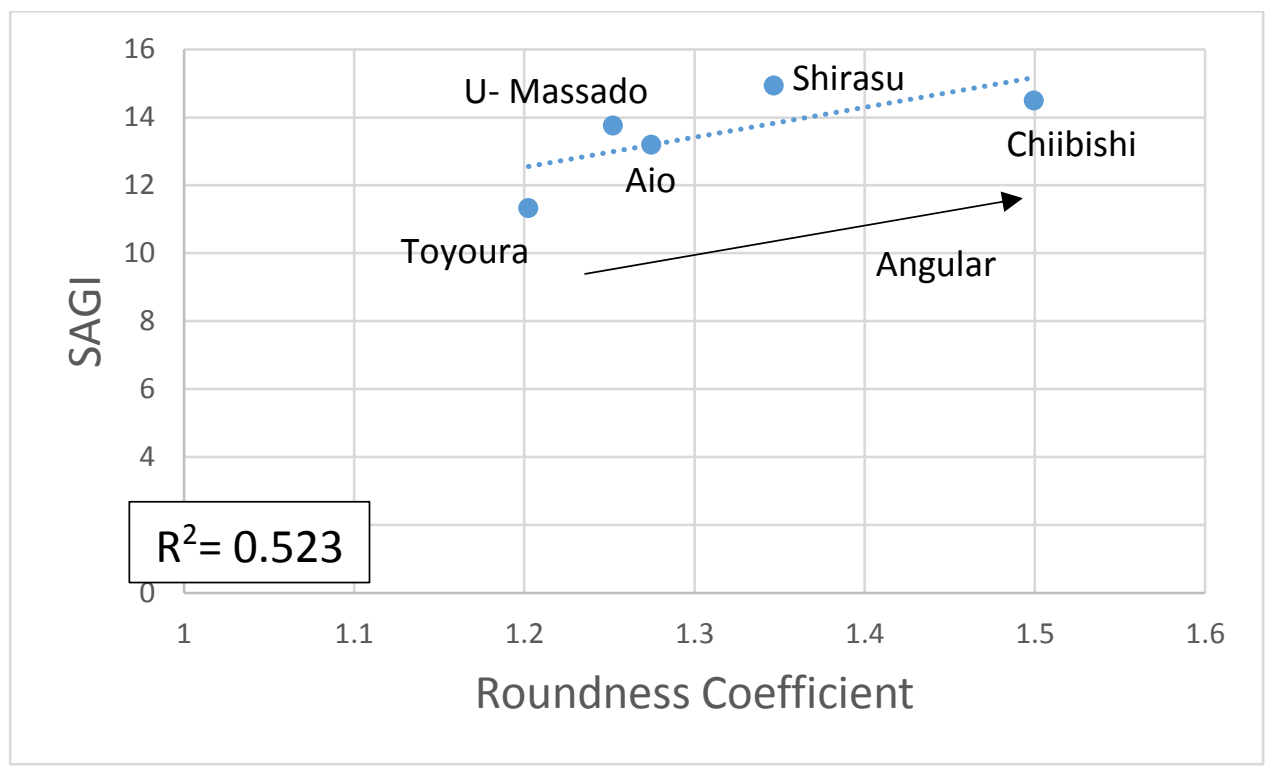

Fig. 3. Comparison of the roundness values calculated by Yoshimoto et al. (2012) and the SAGI factor proposed in this study. 


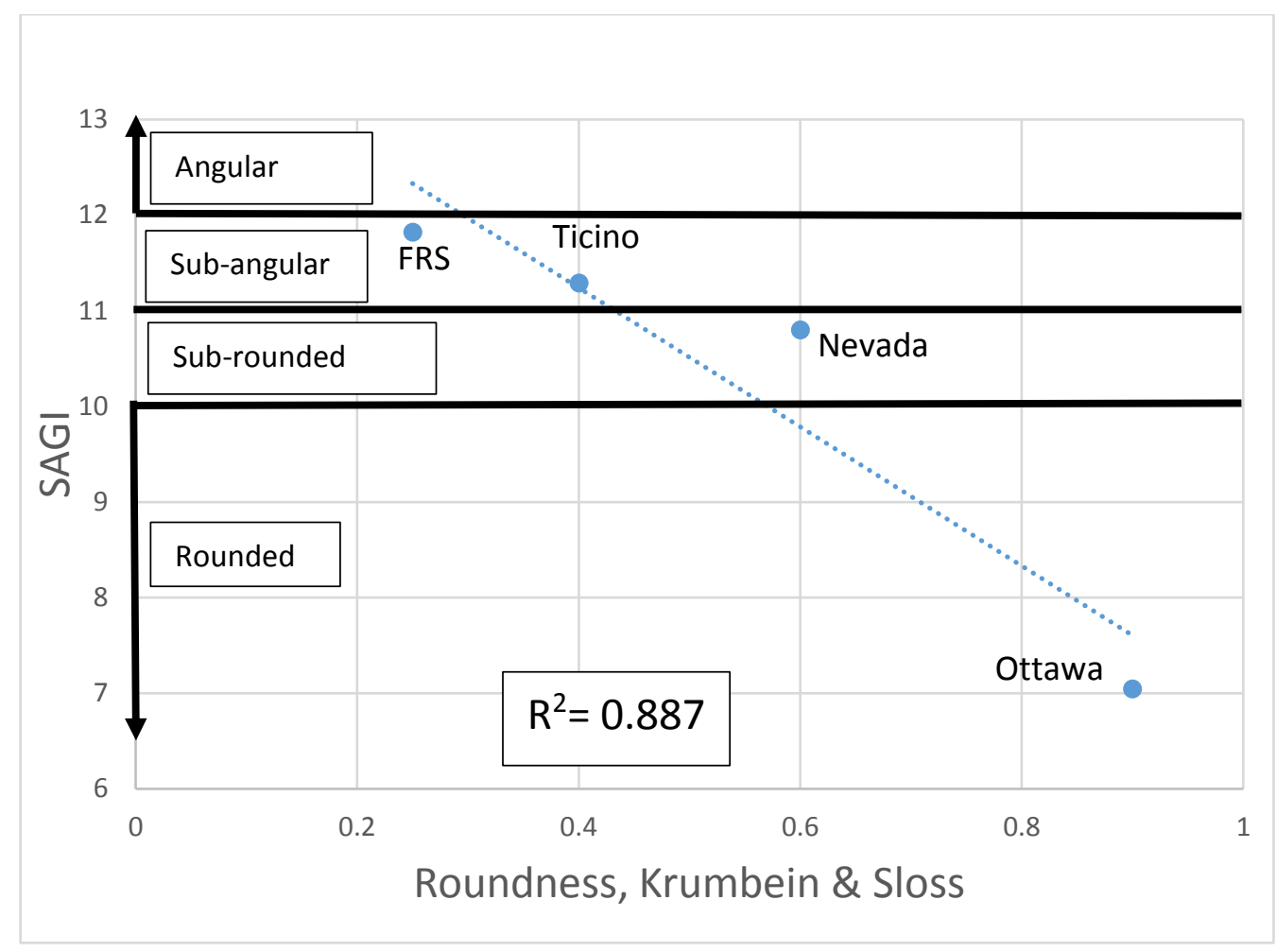

Fig. 4. Comparison of Krumbein \& Sloss (1963) roundness, as reported by Cho et al. 2006 with the SAGI number for some sands in the database. 
SLB

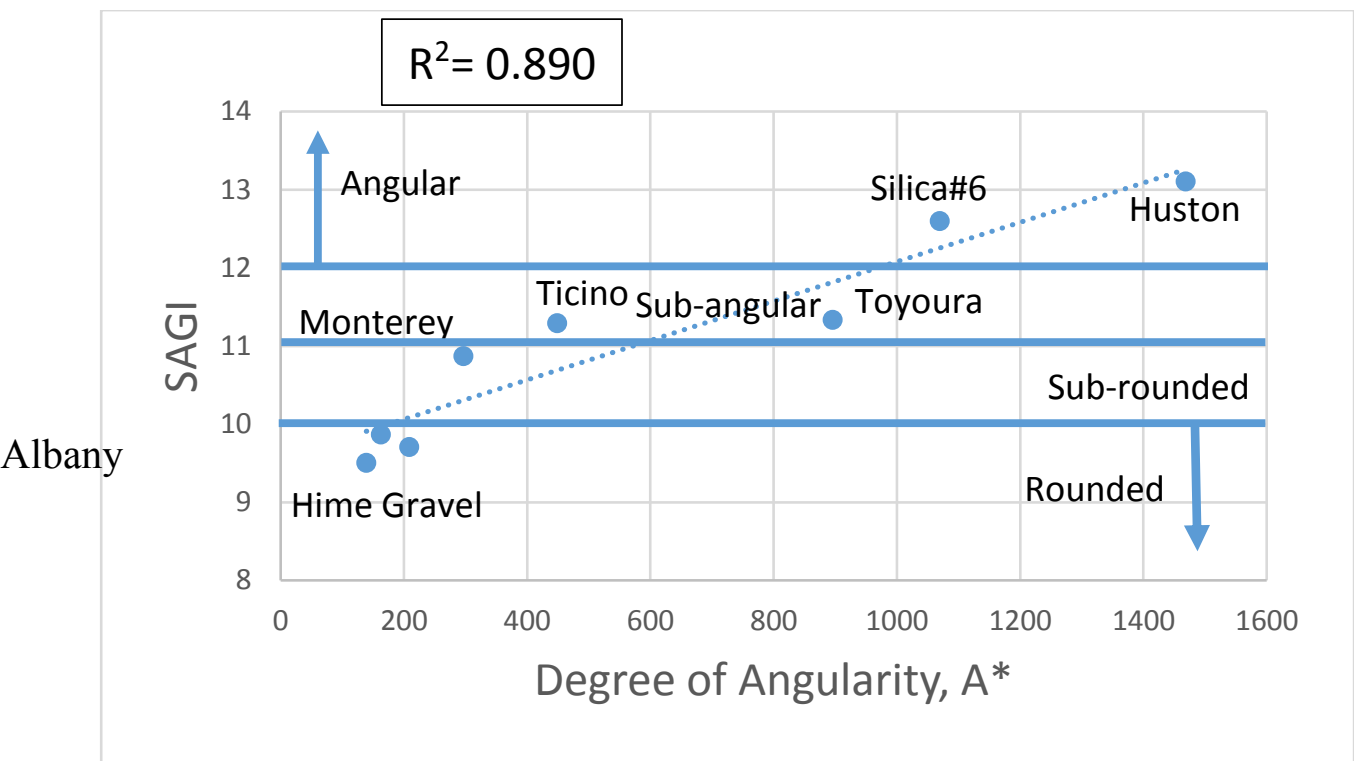

Fig. 5. Comparison between SAGI and Lees' Degree of Angularity for some available soils as reported by Duttine \& Tatsuoka (2009). 


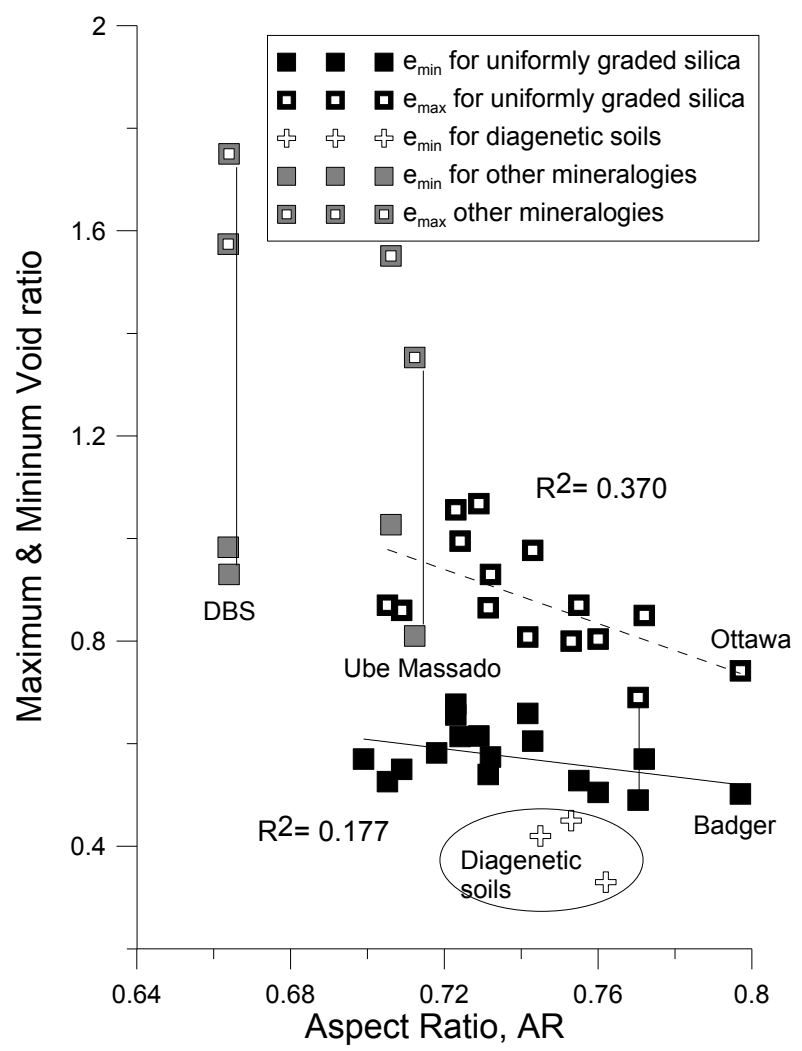

(a) 


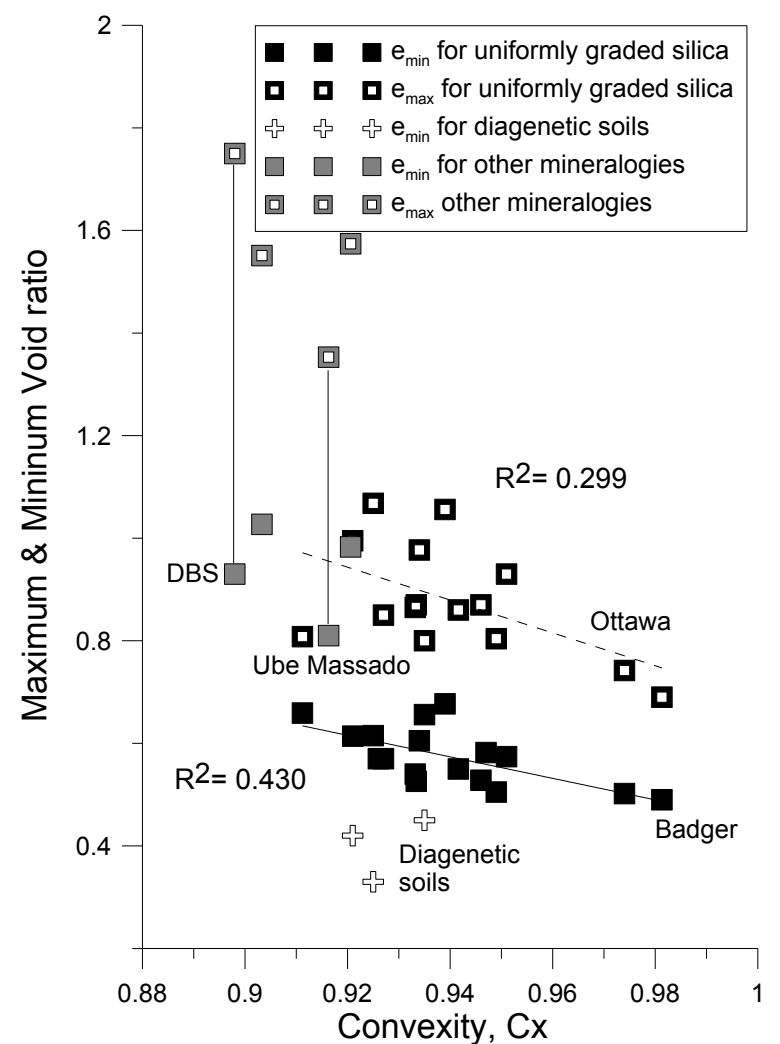

(b) 


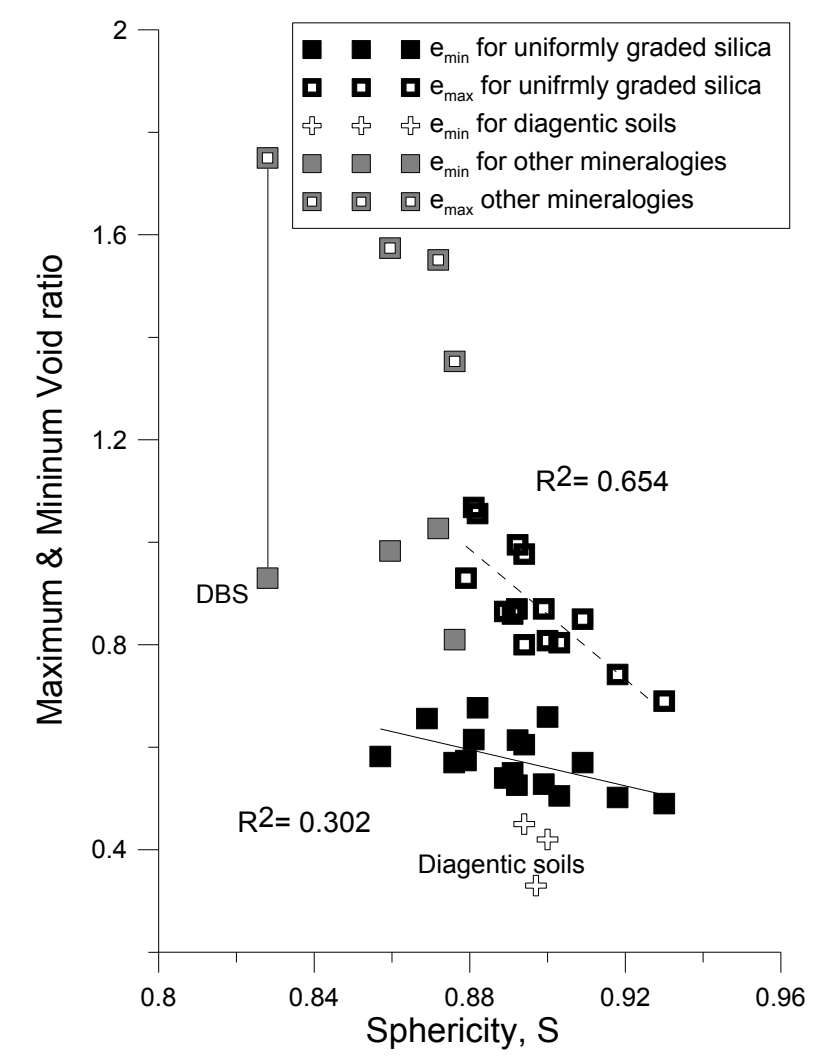

(c) 


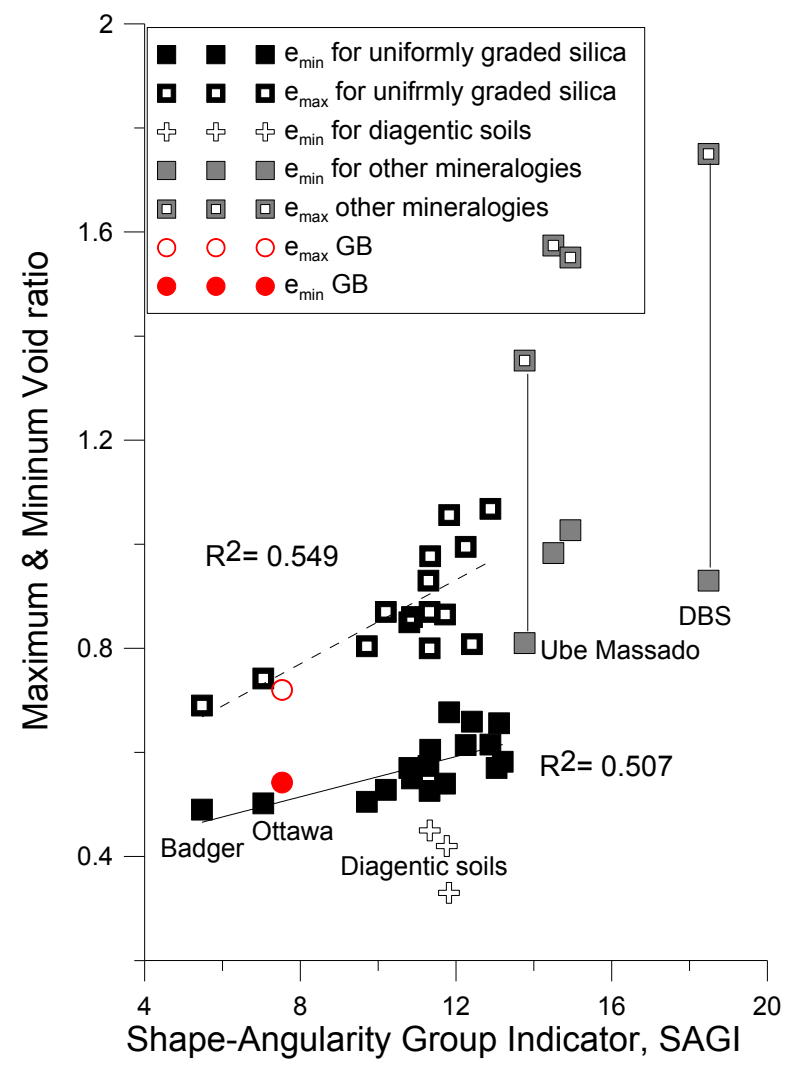

(d)

Fig. 6. Effect of shape factors and SAGI on packing ability of natural sands. 


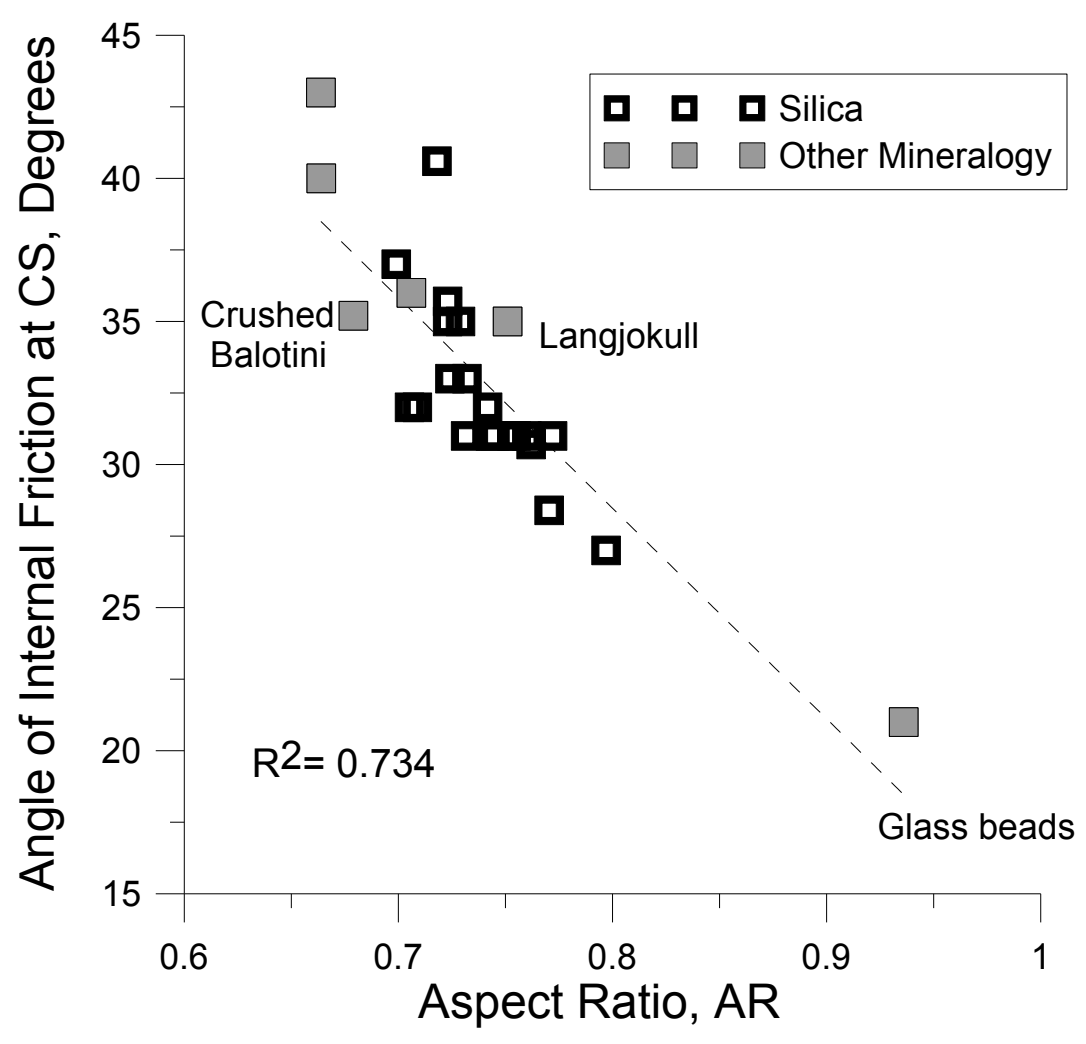

(a) 


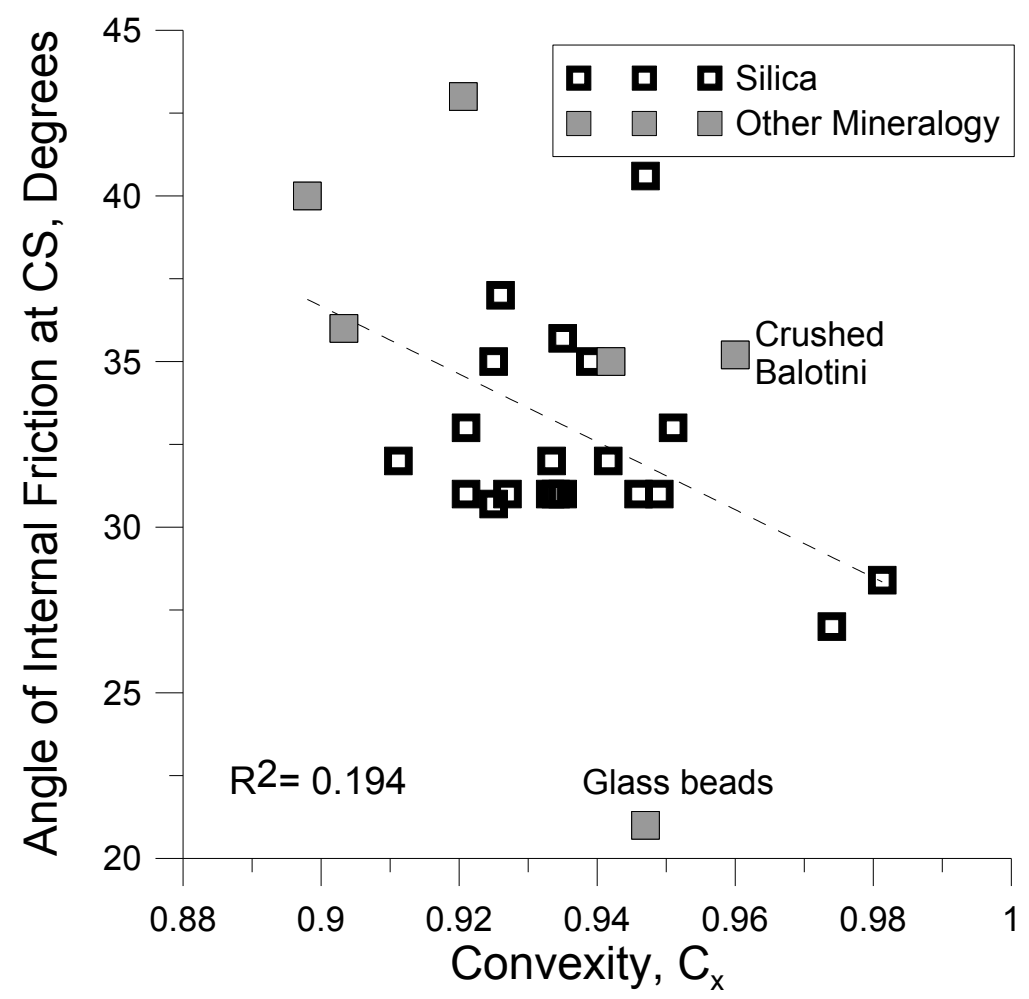

(b) 


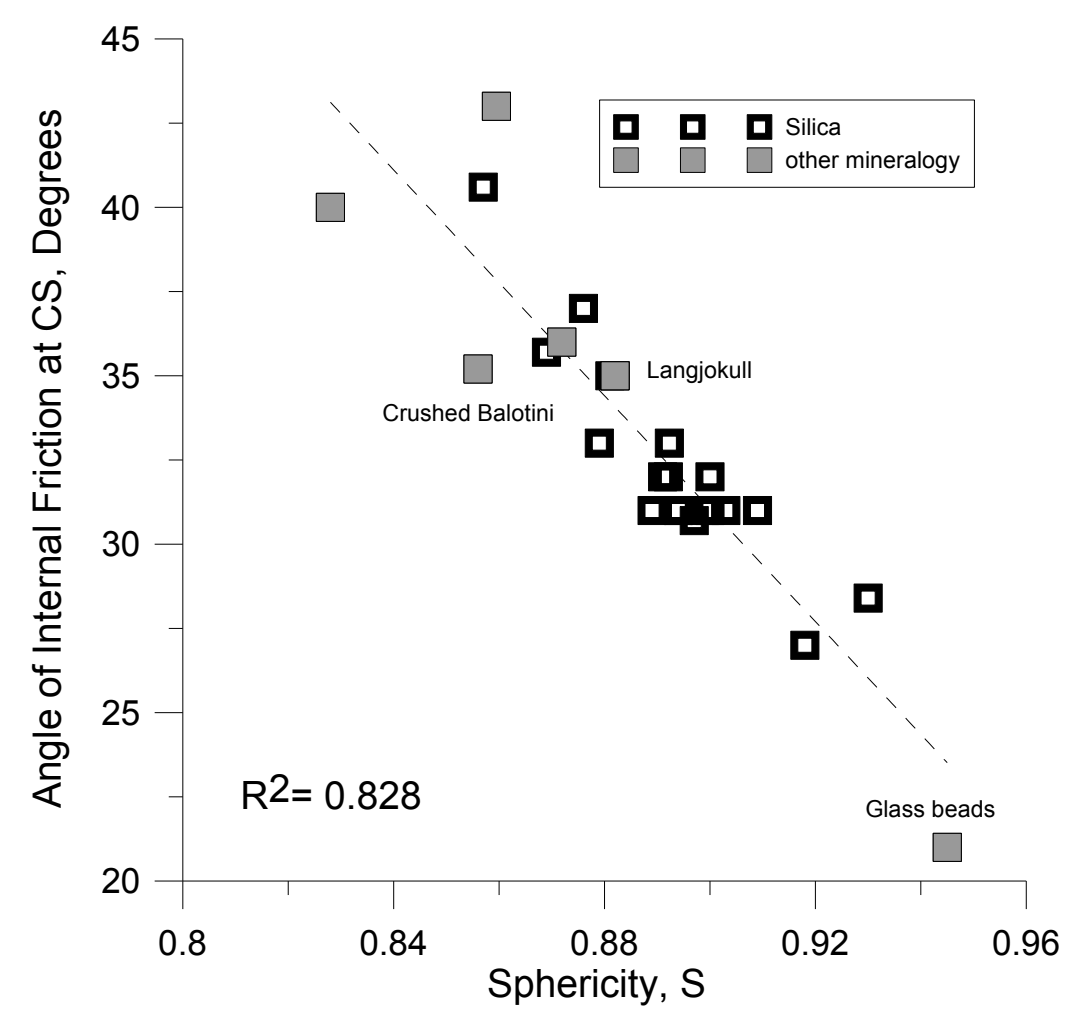

(c) 


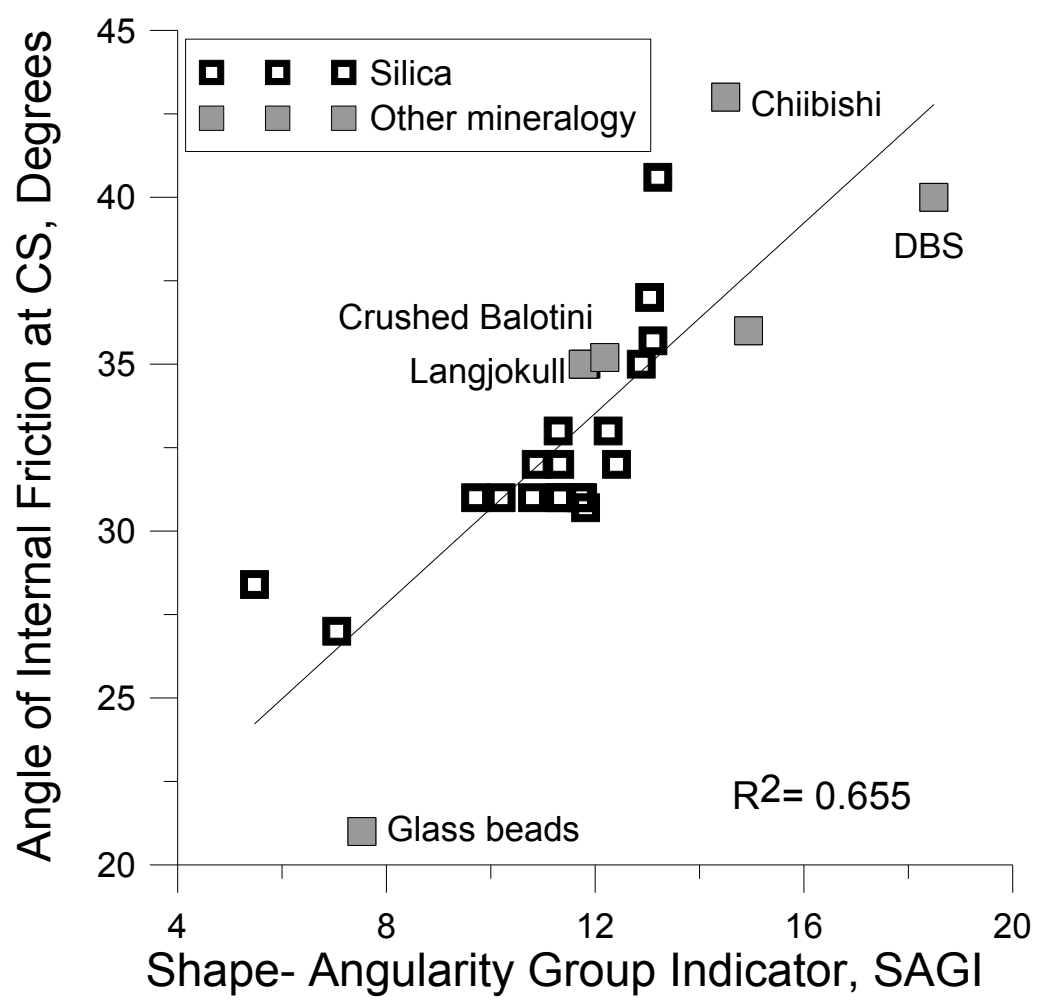

(d)

Fig. 7. Effect of shape factors and SAGI on the internal angle of shearing resistance at Critical State. 


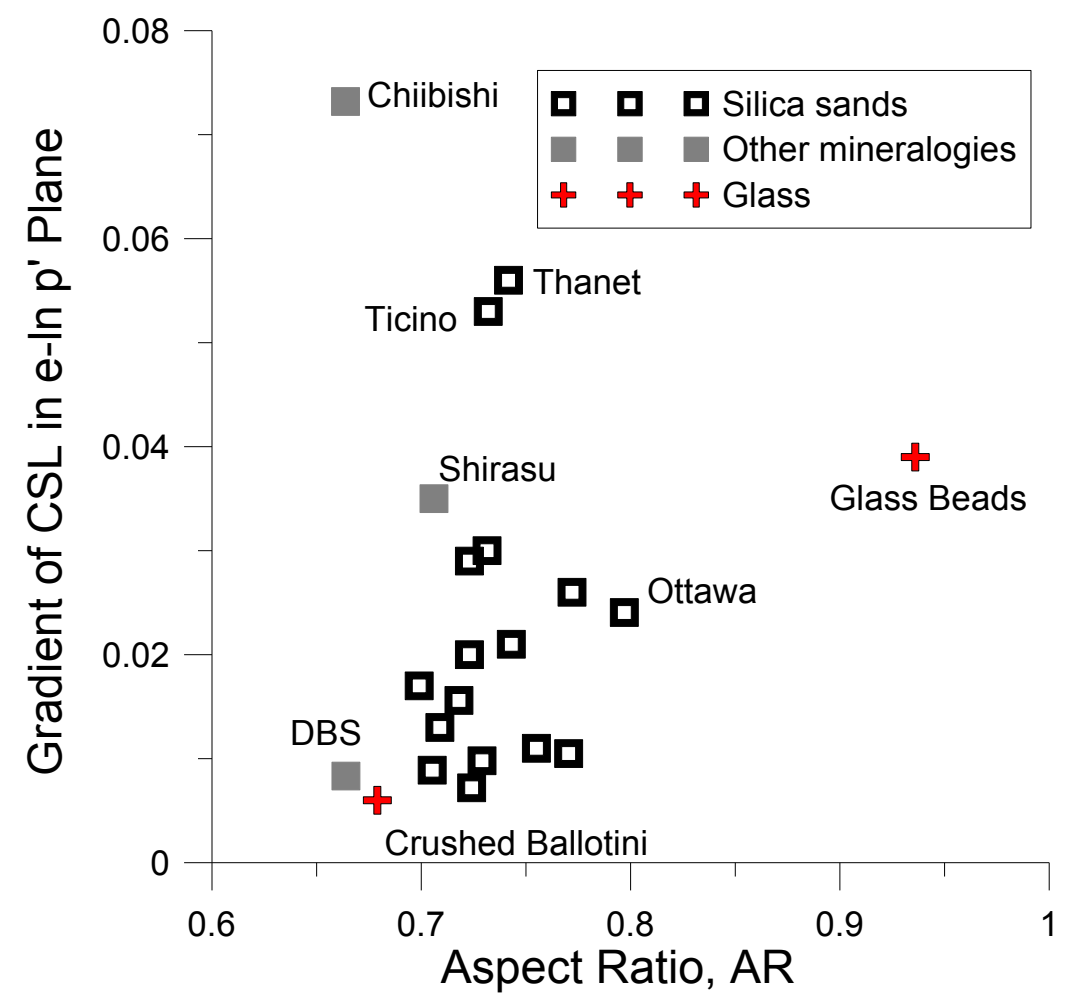

(a) 


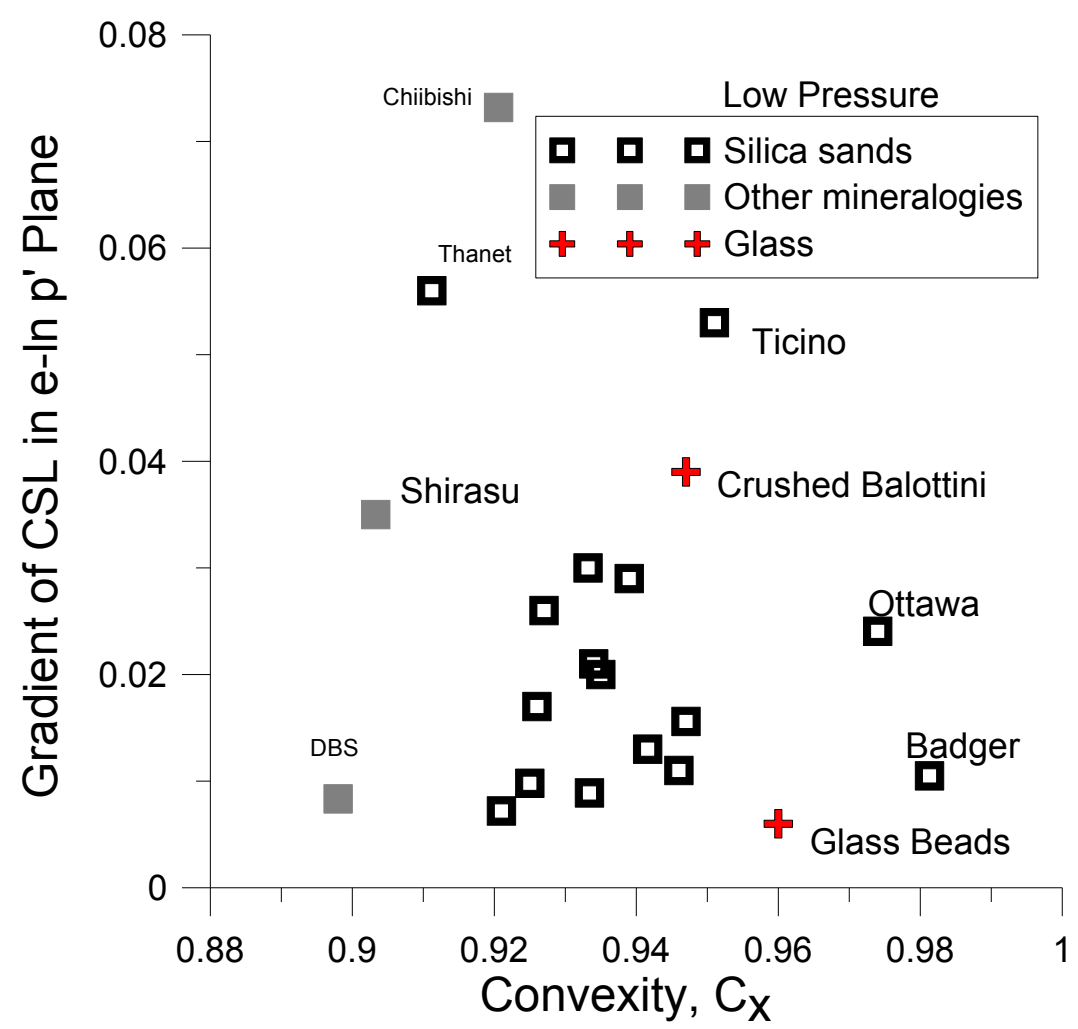

(b) 


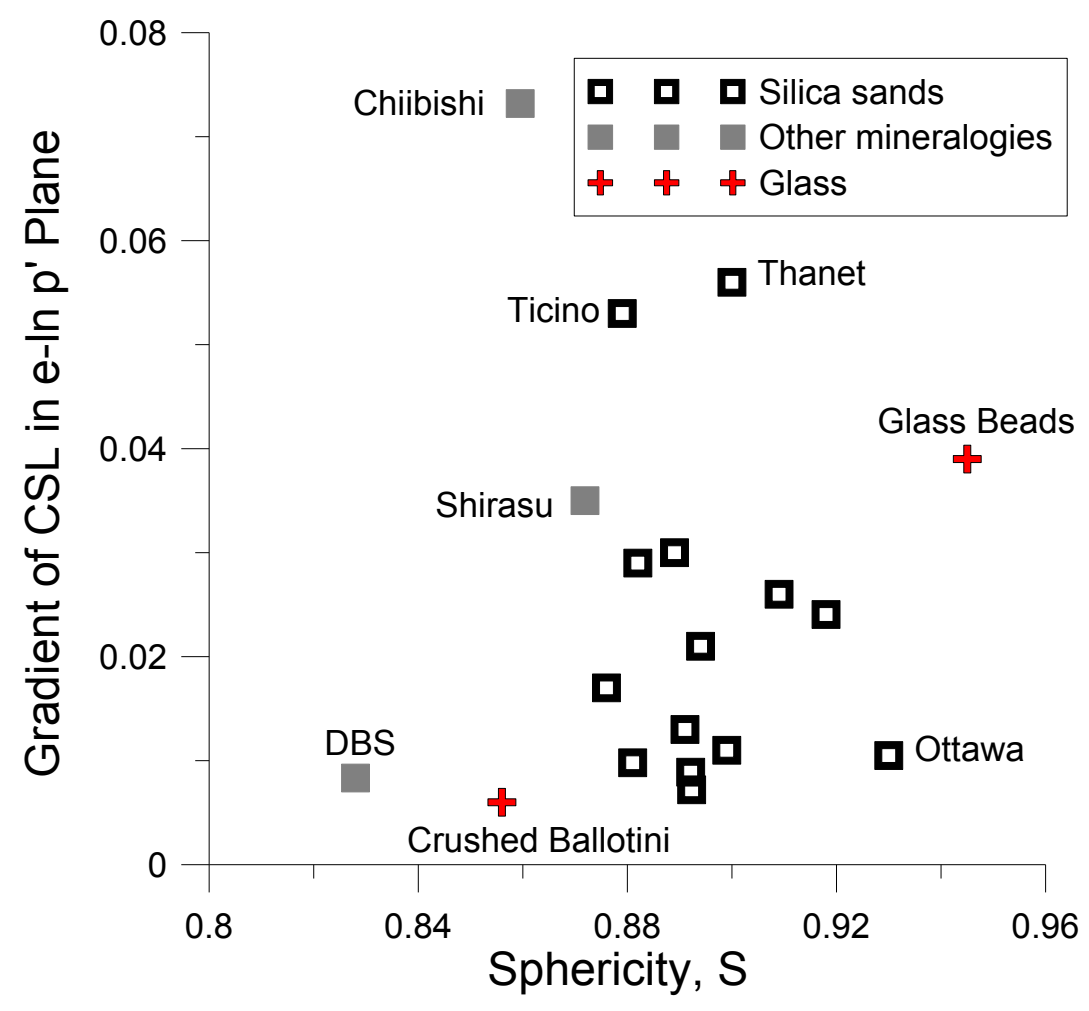

(c) 


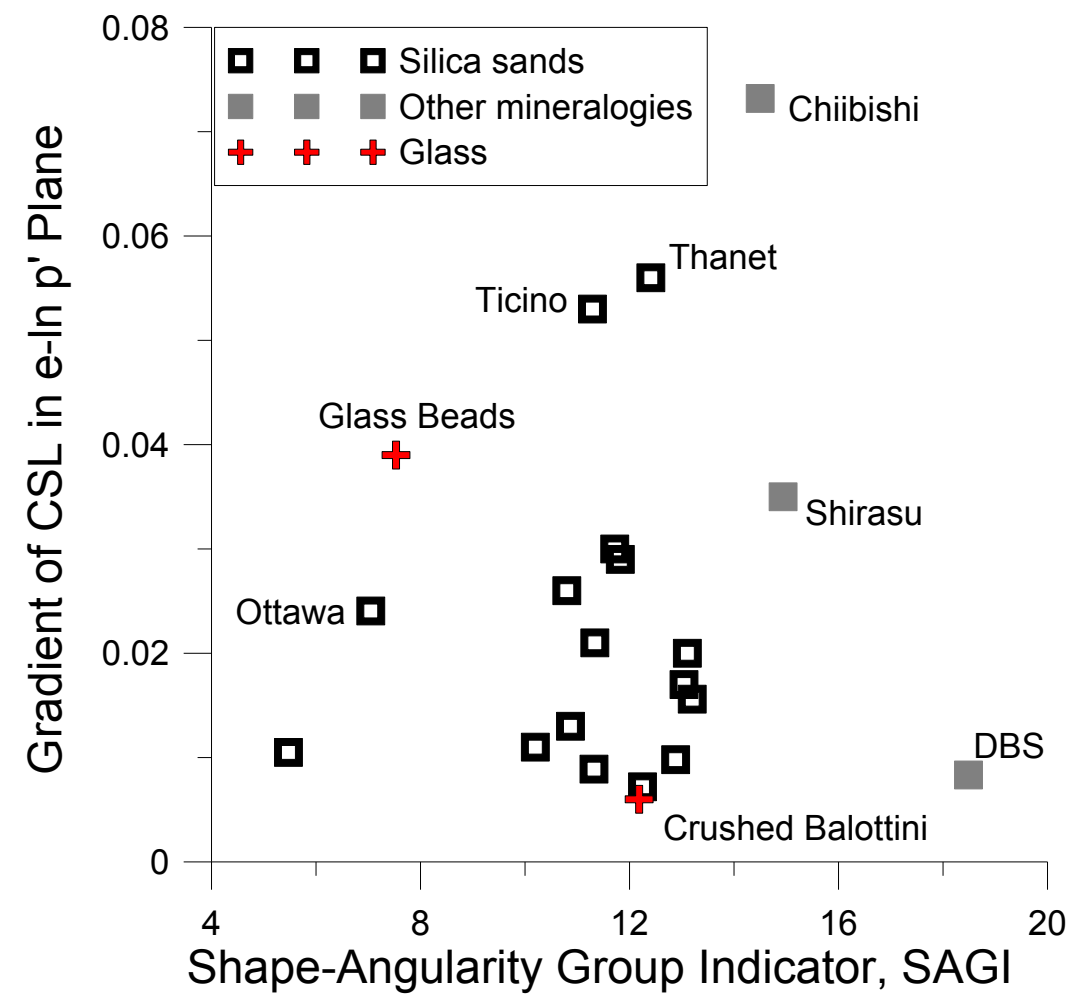

(d)

Fig. 8. Effect of shape and SAGI on the gradient of CSL at low pressure range. 


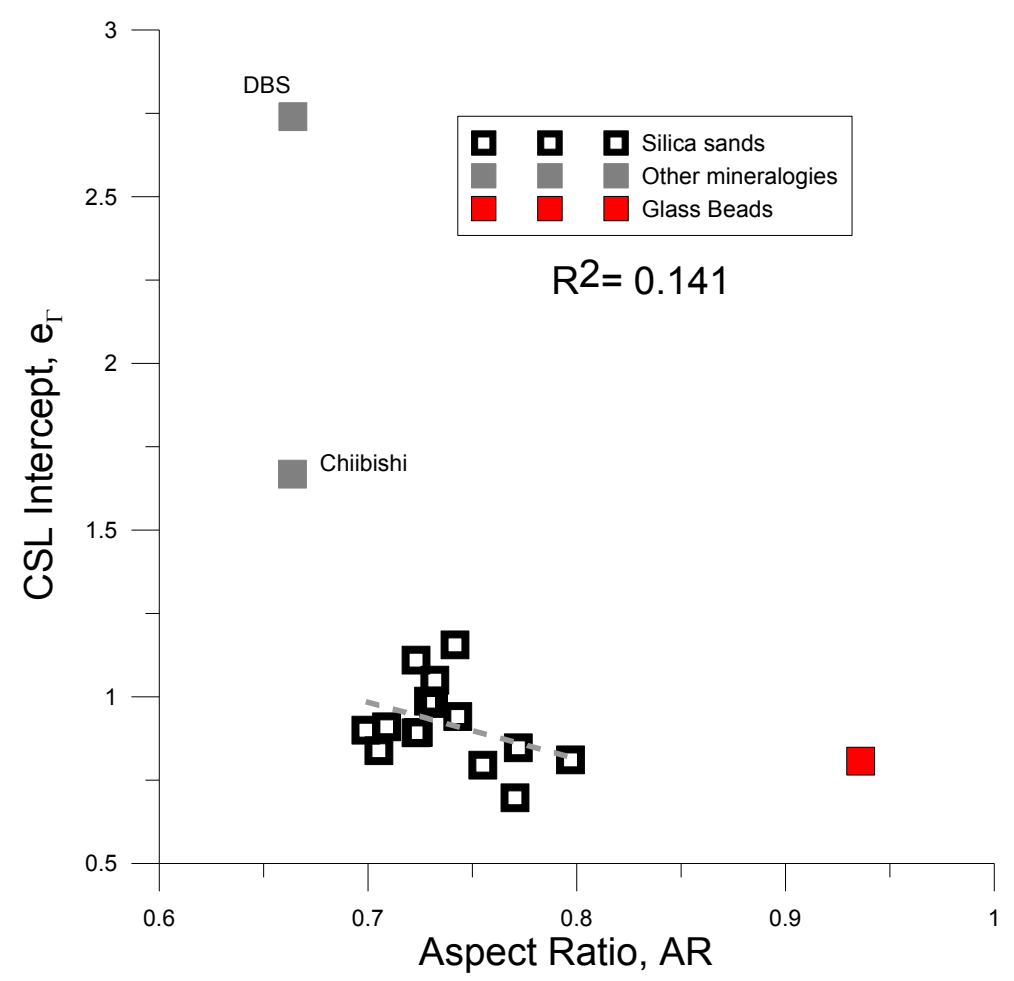

(a) 


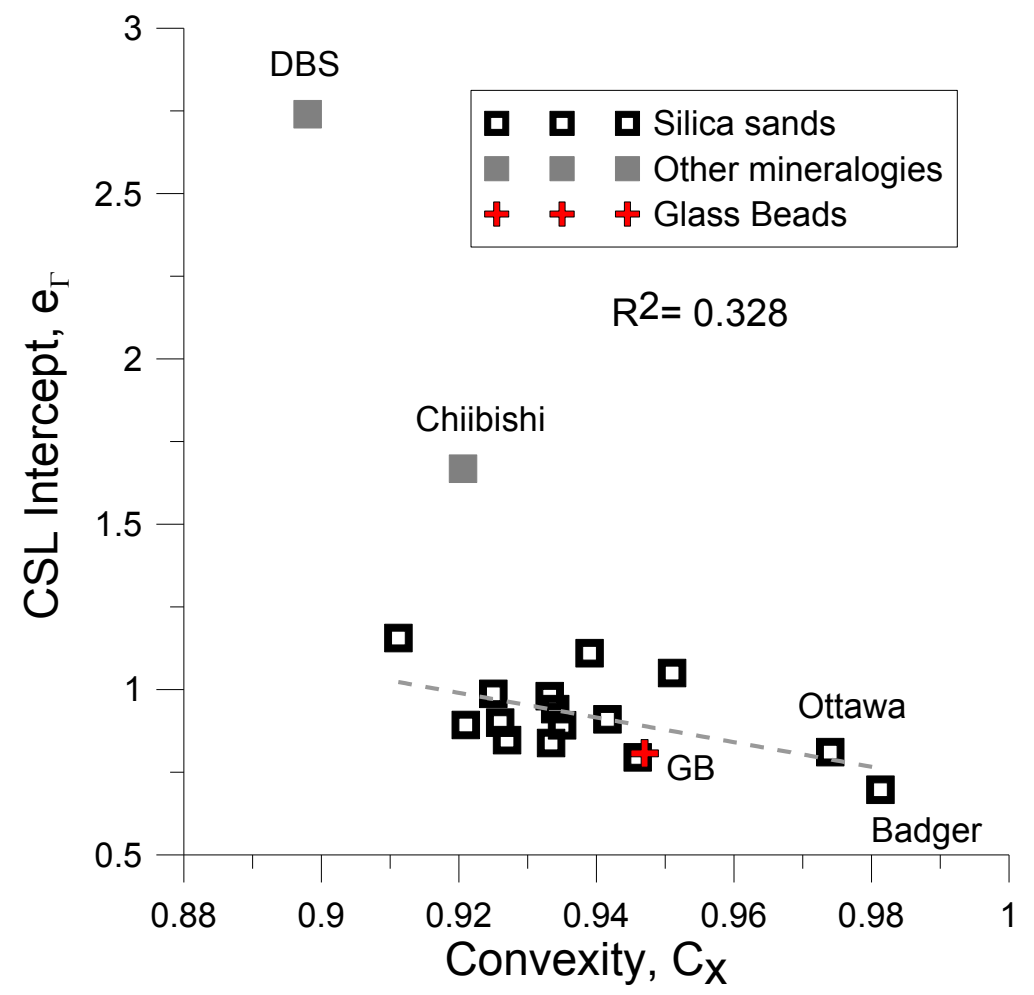

(b) 


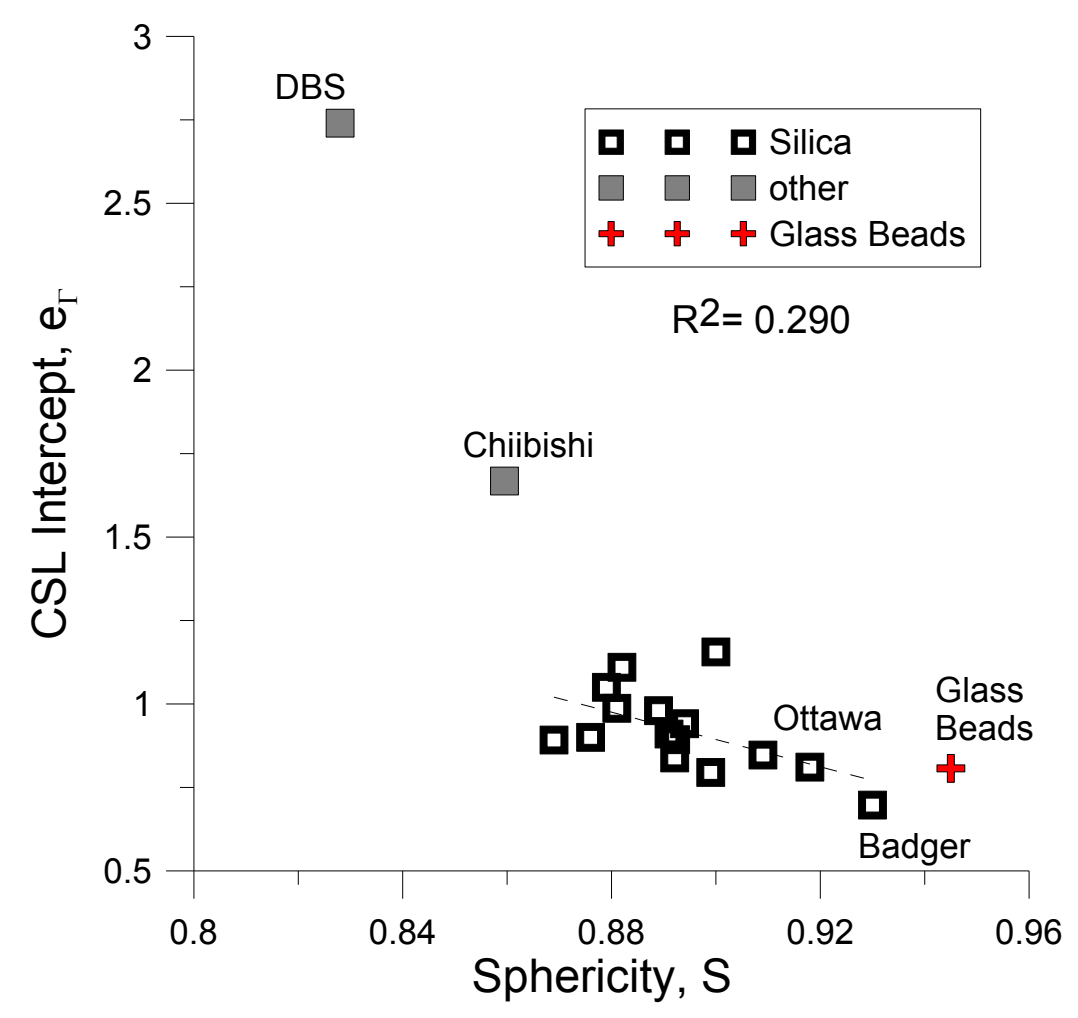

(c) 


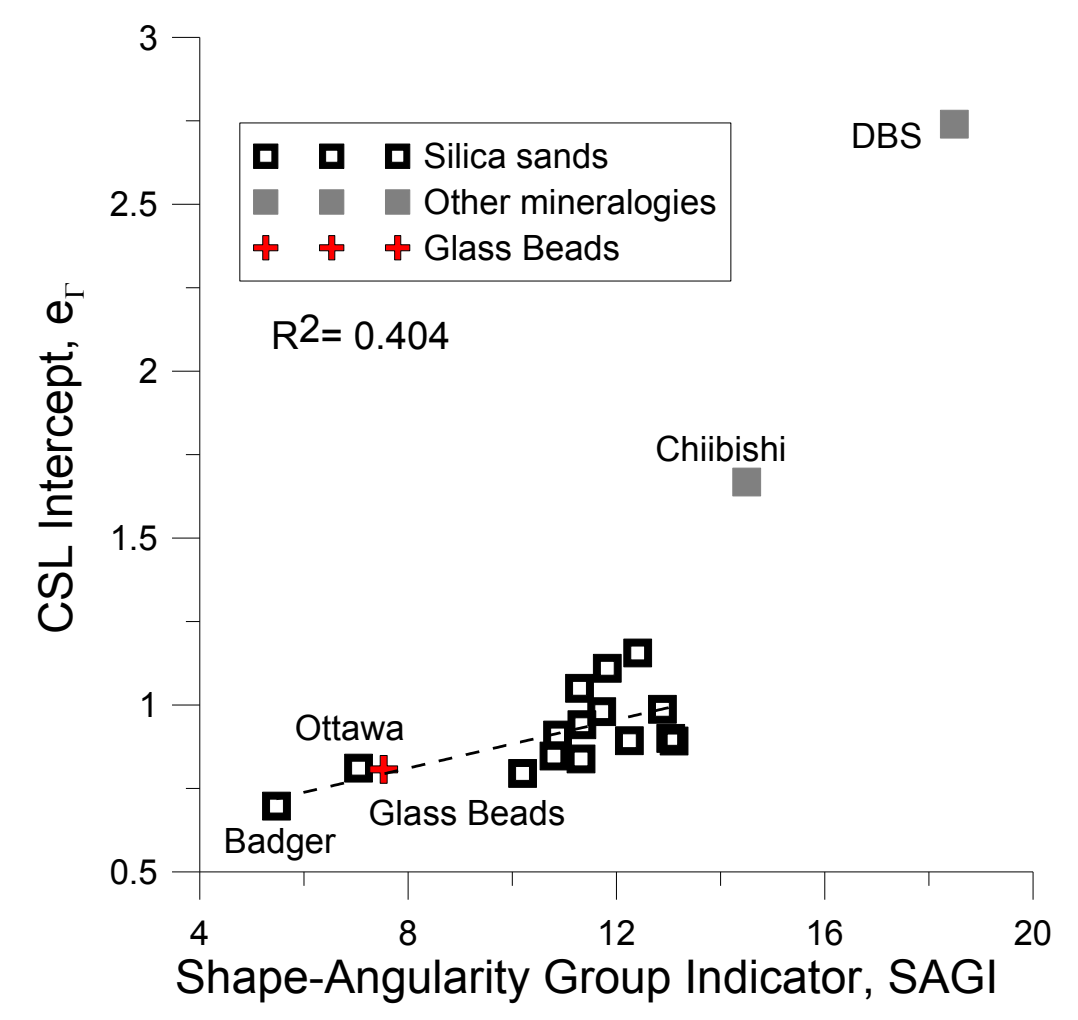

(d)

Fig. 9. Effect of shape and SAGI on the CSL intercept at low pressure range. 


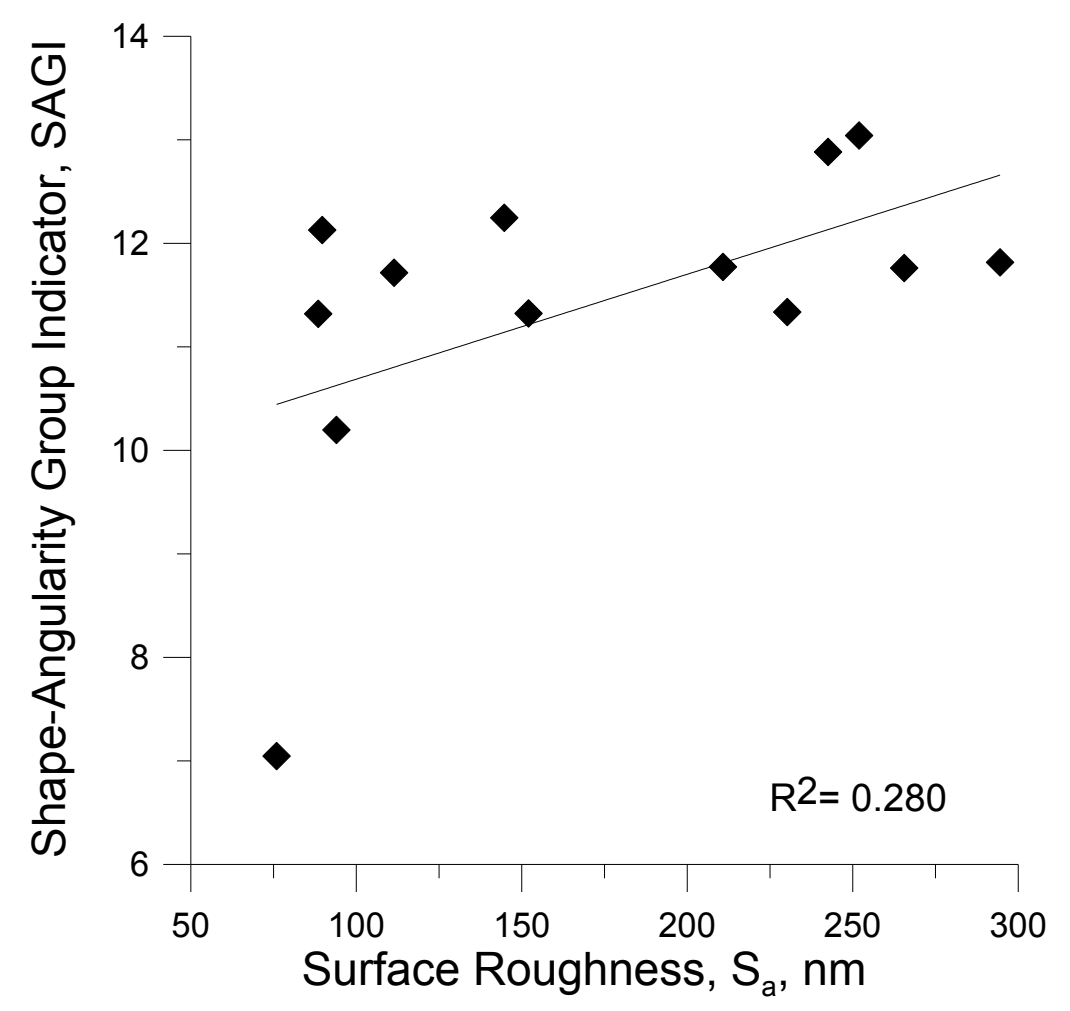

Fig. 10. The relationship between particle shape and roughness. 


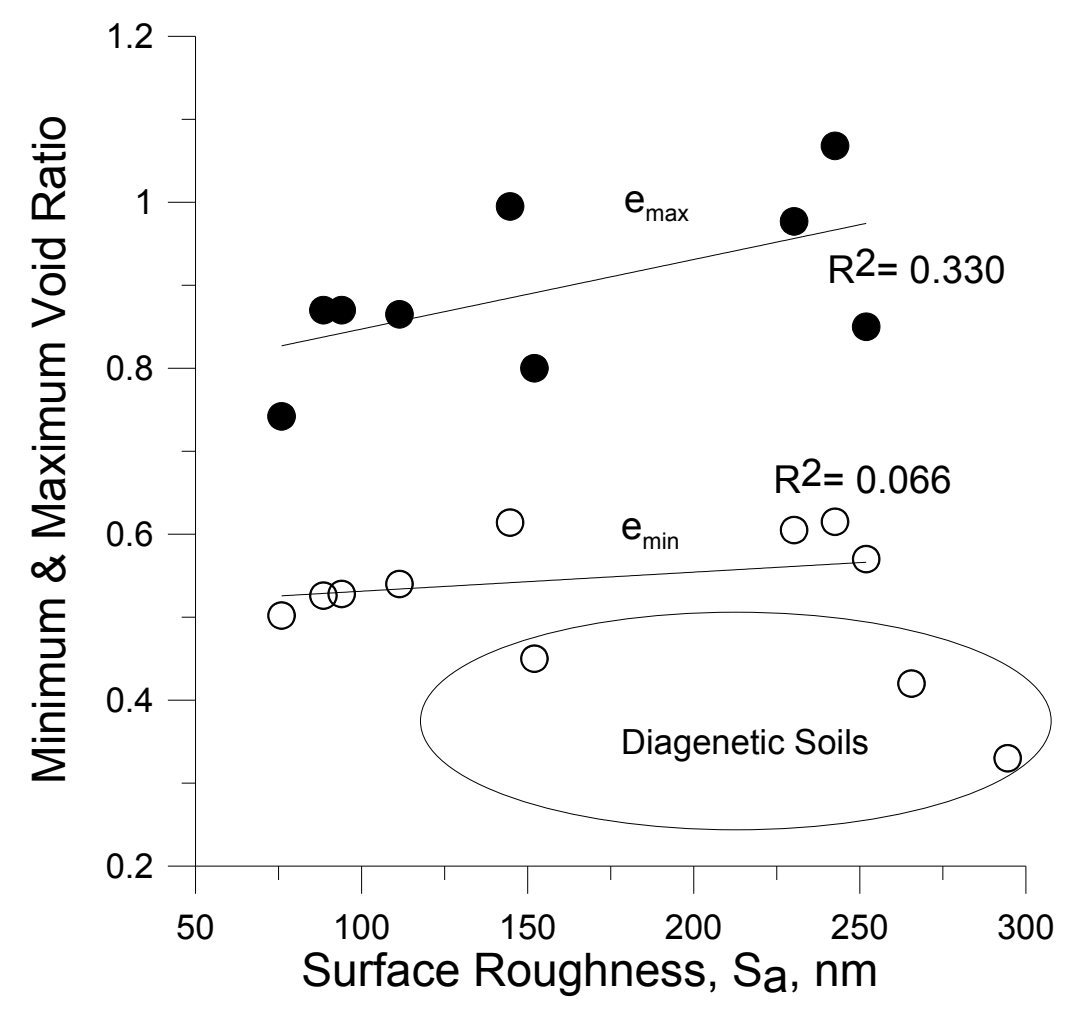

(a) 


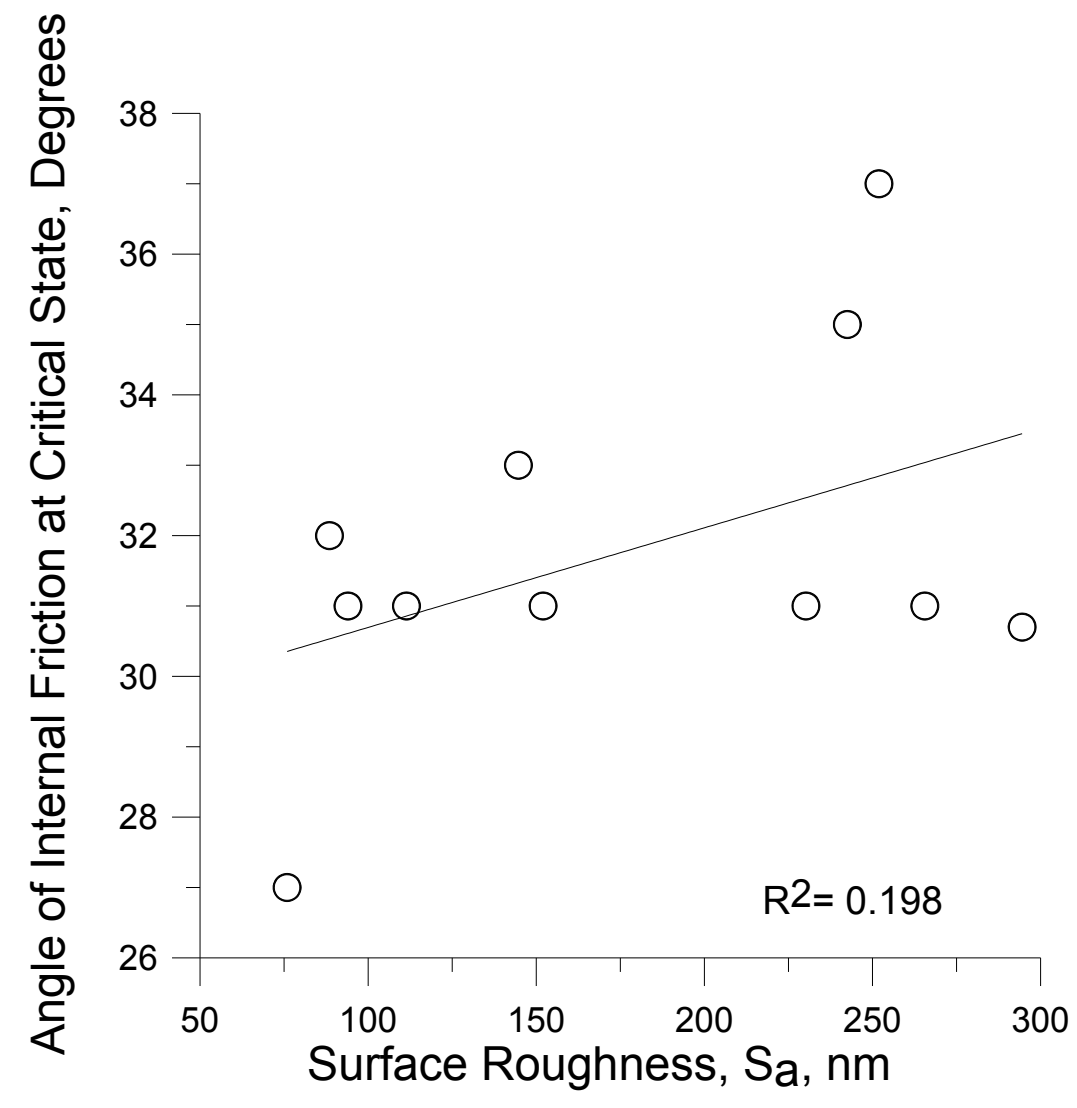

(b) 


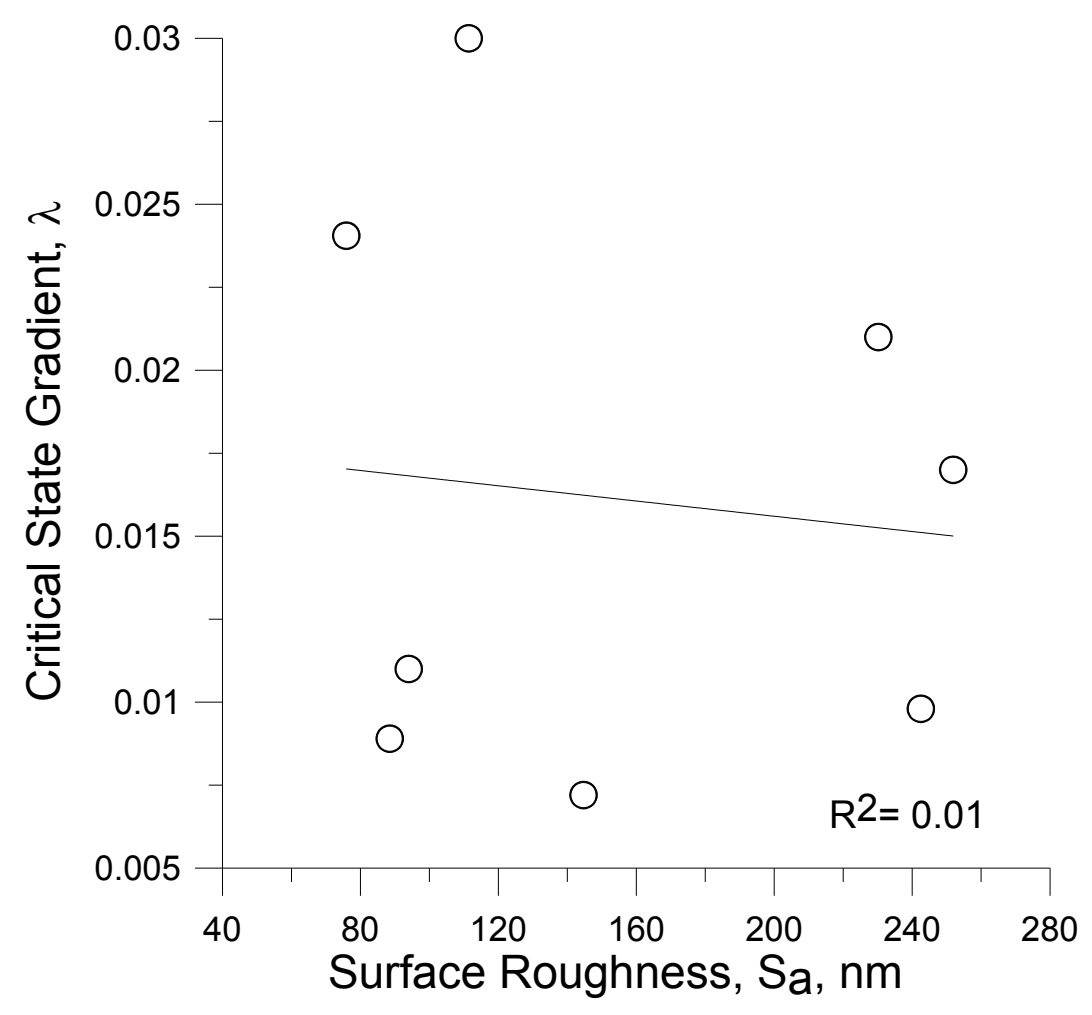

(c) 


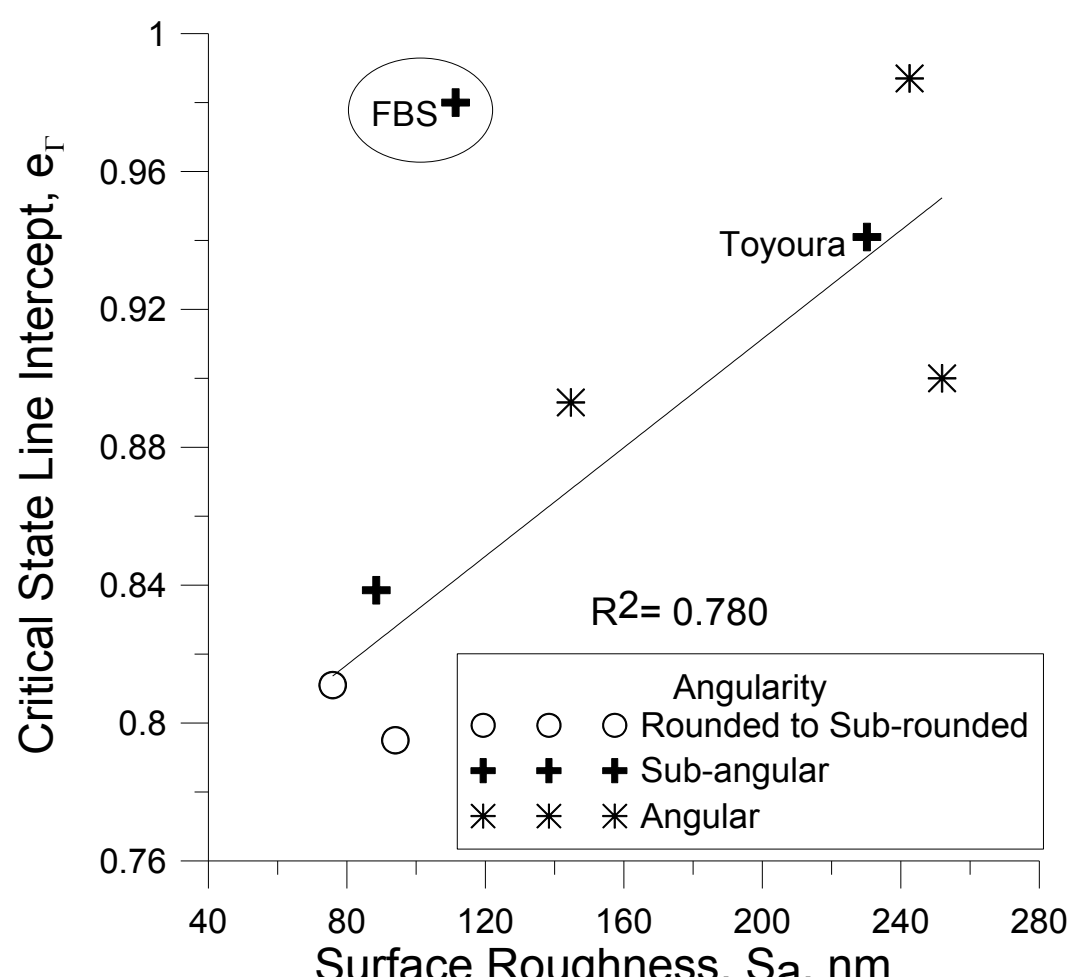

(d)

Fig. 11. Effect of particle surface roughness of soils on (a) Packing, (b) Angle of shearing resistance at CS, (c) Gradient of CSL and (d) Critical State line intercept. 


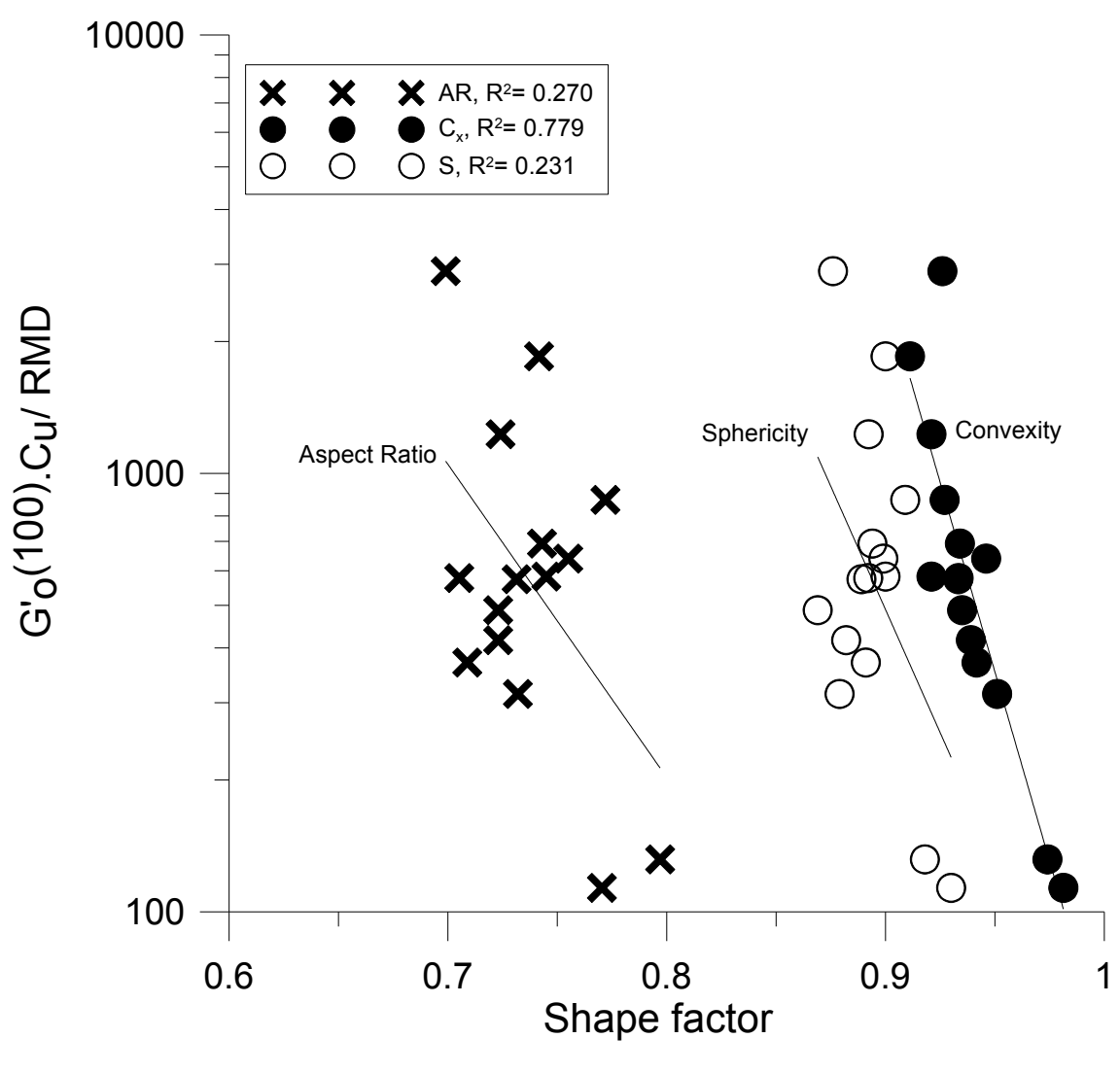

(a) 


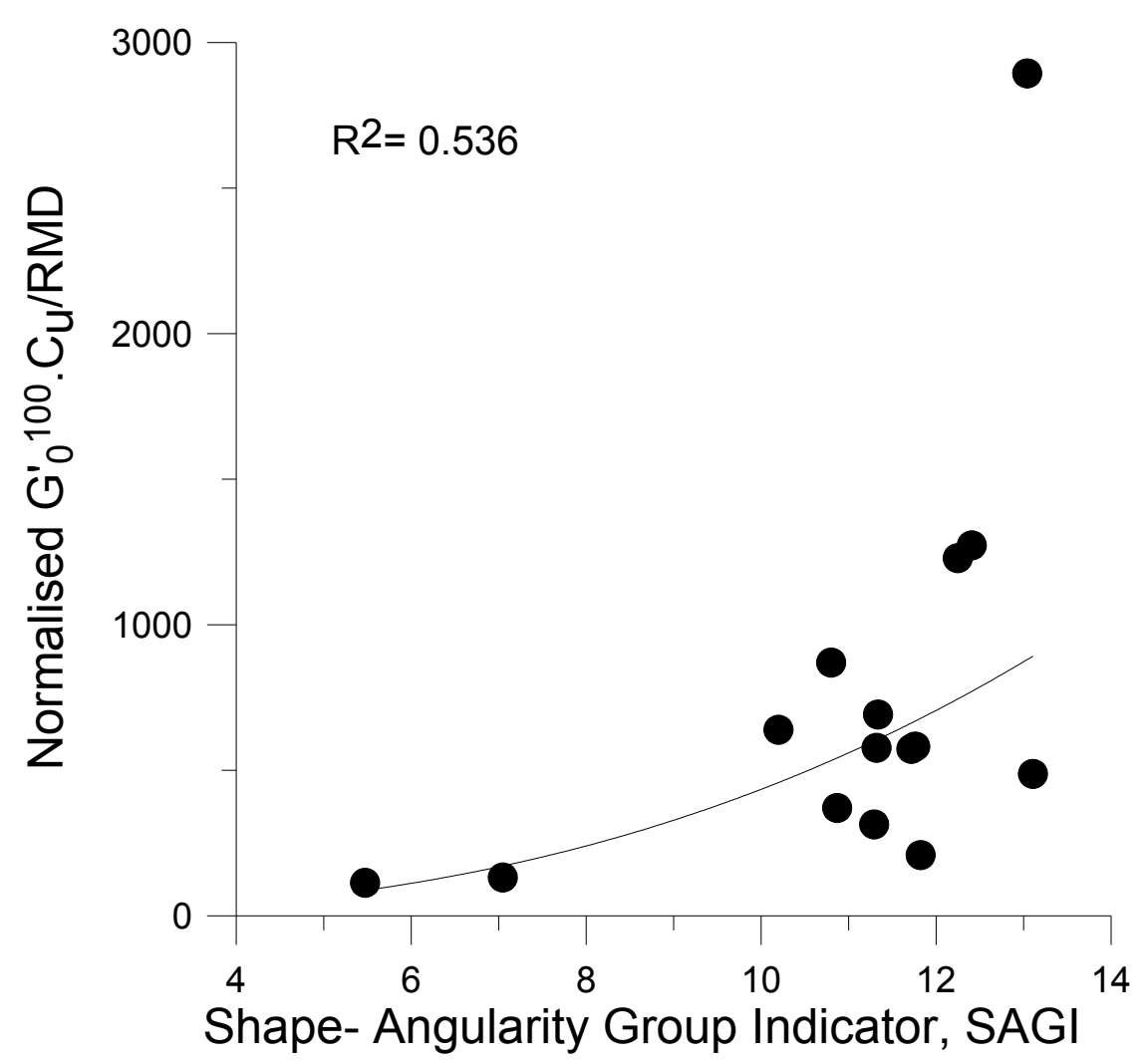

(b) 


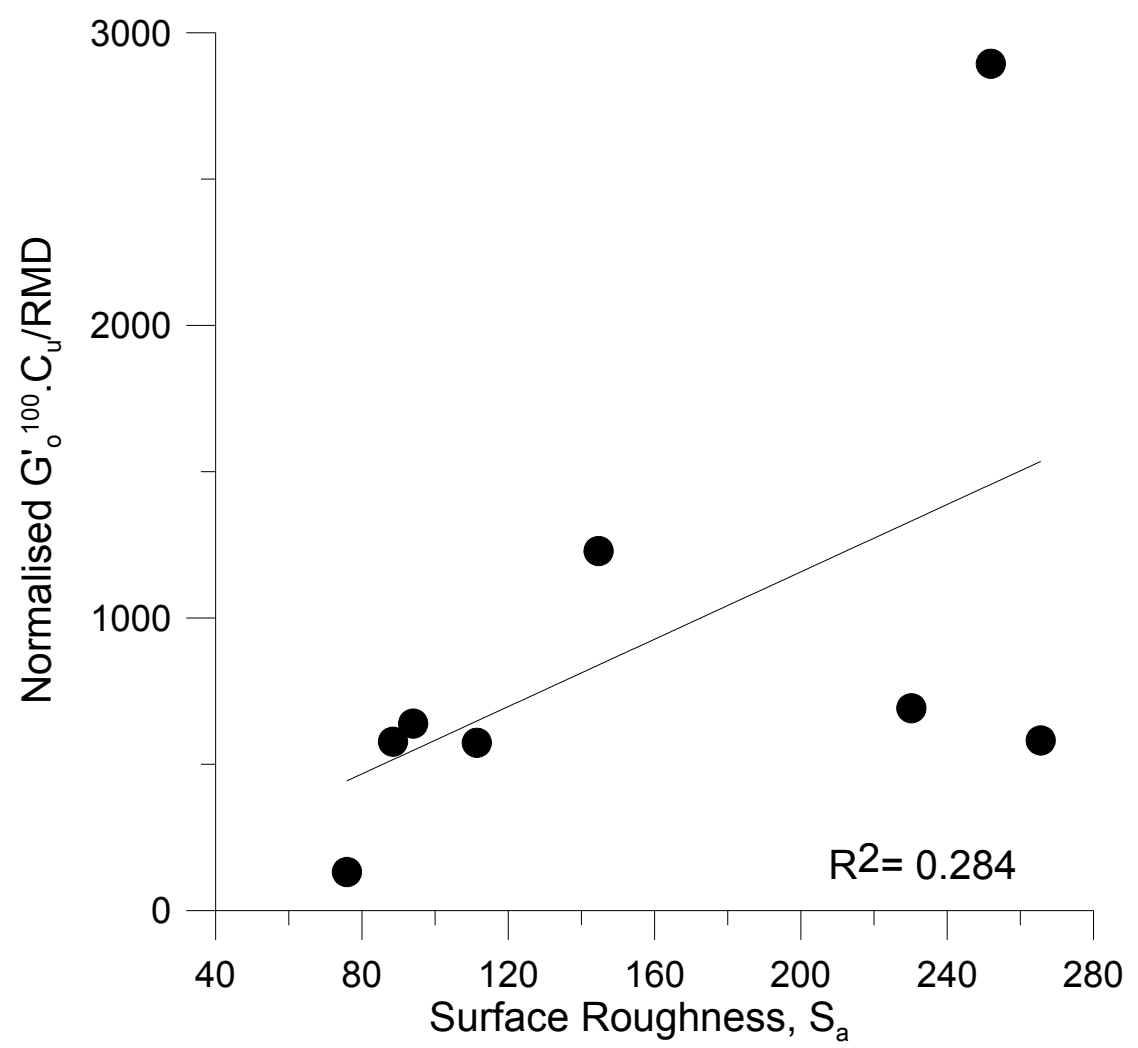

(c)

Fig. 12. Effect of shape and roughness on the normalized elastic shear modulus of silica sands (a) Effect of shape separate parameters (b) effect of SAGI (c) effect of surface roughness 
Table 1. Database of natural sands, summary of their geological history, packing and critical state properties from previous research (underlined names indicate quarried sands).

\begin{tabular}{|c|c|c|c|c|c|c|c|c|c|c|}
\hline Sand & Geological Facts & Location & $\mathbf{e}_{\min }$ & $\mathbf{e}_{\max }$ & $\phi^{\prime} c s$ & $\lambda_{\text {(high) }}$ & $\Gamma_{\text {(high) }}$ & $\lambda_{\text {(low) }}$ & $\Gamma_{\text {(low) }}$ & Reference: \\
\hline Badger sand & $\begin{array}{l}\text { Uniformly graded silica } \\
\text { (rounded) }\end{array}$ & $\begin{array}{l}\text { USA } \\
\text { Mining }\end{array}$ & 0.49 & 0.69 & 28.4 & & & 0.0105 & 0.697 & $\begin{array}{l}\text { Rouse et al., 2014; Rouse, } \\
2003 .\end{array}$ \\
\hline$\frac{\text { Ottawa }}{(20 / 30)}$ & $\begin{array}{l}\text { Nearly pure silica sand from } \\
\text { the St. Peter sandstone } \\
\text { deposits. }\end{array}$ & $\begin{array}{l}\text { North } \\
\text { America }\end{array}$ & 0.502 & 0.742 & 27 & & & 0.024 & 0.802 & $\begin{array}{l}\text { Santamarina \& Cho, 2001; } \\
\text { Salgado et al., } 2000 .\end{array}$ \\
\hline Albany & Fine silica sand & Australia & 0.505 & 0.804 & 31 & & & & & Duttine \& Tatsuoka, 2009. \\
\hline M31 & $\begin{array}{l}\text { Silica sand with polished } \\
\text { grain surface indicating origin } \\
\text { from a marine environment. }\end{array}$ & Belgium & 0.528 & 0.87 & 31 & & & 0.011 & 0.795 & $\begin{array}{l}\text { Tsomokos \& Georgiannou, } \\
2010 .\end{array}$ \\
\hline
\end{tabular}




\begin{tabular}{|c|c|c|c|c|c|c|c|c|c|c|}
\hline Monterey(0) & $\begin{array}{l}\text { Rounded-sub-rounded } \\
\text { predominantly silica and } \\
\text { feldspar and some mica. } \\
\text { (beach sand) }\end{array}$ & USA & 0.55 & 0.86 & 32 & & & 0.013 & 0.91 & Saxena \& Reddy, 1989. \\
\hline Nevada & Uniform fine silica sand & USA & 0.57 & 0.85 & 31 & & & 0.026 & 1.04 & $\begin{array}{l}\text { Yamamuro \& Lade 1997; } \\
\text { Yun \& Santamarina, } 2005 .\end{array}$ \\
\hline Ticino & $\begin{array}{l}\text { Uniform coarse-medium } \\
\text { sand. Mainly sub-angular } \\
\text { silica grains. Silica }(28 \%) \text {, } \\
\text { feldspar }(30 \%) \text { mica }(5 \%) \text {, } \\
\text { opaque }\end{array}$ & $\begin{array}{l}\text { Ticino River } \\
\text { Switzerland }\end{array}$ & 0.574 & 0.93 & 33 & & & 0.053 & 1.05 & $\begin{array}{l}\text { Santamarina \& Cho, 2001; } \\
\text { Bellotti et al., } 1996 .\end{array}$ \\
\hline$\frac{\text { Ham River }}{\text { (HRS) }}$ & $\begin{array}{l}\text { Poorly graded quarried silica } \\
\text { sand, typical river } \\
\text { transported soil. }\end{array}$ & $\begin{array}{l}\text { Chertsey- } \\
\text { England }\end{array}$ & 0.526 & 0.87 & 32 & 0.16 & 1.99 & 0.0089 & 0.839 & $\begin{array}{l}\text { Coop \& Lee 1993; Jovicic \& } \\
\text { Coop, } 1997 .\end{array}$ \\
\hline $\begin{array}{l}\text { Greensand } \\
\text { (GS) }\end{array}$ & $\begin{array}{l}\text { Diagenetic (Lower } \\
\text { Cretaceous) medium- to fine- } \\
\text { grained silica sands. }\end{array}$ & $\begin{array}{l}\text { Folkestone } \\
\text { UK }\end{array}$ & $0.45^{*}$ & 0.8 & 31 & 0.155 & 1.24 & & & Cuccovillo \& Coop, 1997. \\
\hline Toyoura & $\begin{array}{l}\text { Uniformly graded sub- } \\
\text { rounded to sub-angular fine } \\
\text { sand composed of } 75 \% \\
\text { silica, } 22 \% \text { feldspar } \\
\text { and } 3 \% \text { magnetite }\end{array}$ & Japan & 0.605 & 0.977 & 31 & 0.198 & 1.912 & 0.021 & 0.941 & $\begin{array}{l}\text { Verdugo \& Ishihara 1996; } \\
\text { Bellotti et al., } 1996 .\end{array}$ \\
\hline Sand & Geological Facts & Location & $\mathbf{e}_{\min }$ & $\mathbf{e}_{\max }$ & $\phi c s$ & $\lambda_{\text {(high) }}$ & $\Gamma_{\text {(high) }}$ & $\lambda_{\text {(low) }}$ & $\Gamma_{\text {(low) }}$ & Ref: \\
\hline$\frac{\text { Fontainbleau }}{\text { (FBS) }}$ & $\begin{array}{l}\text { NE34, silica sand quarried } \\
\text { from south of Paris. }\end{array}$ & France & 0.54 & 0.865 & 31 & 0.123 & 1.655 & 0.03 & 0.98 & $\begin{array}{l}\text { Dano \& Hicher, 2003; } \\
\text { Delfosse -Ribay et al., 2004; } \\
\text { Hicher et al., 2008; Salgado } \\
\text { et al., 2000. }\end{array}$ \\
\hline $\begin{array}{l}\text { Saltwash } \\
\text { (SW) }\end{array}$ & $\begin{array}{l}\text { Diagenetic. Dense analogue } \\
\text { reservoir silica sandstone, } \\
\text { tested reconstituted. }\end{array}$ & $\begin{array}{l}\text { Colorado- } \\
\text { Utah, USA. }\end{array}$ & $0.42^{*}$ & & 31 & 0.149 & 1.82 & & & $\begin{array}{l}\text { Alvarado ,2007, Alvarado et } \\
\text { al., } 2012 .\end{array}$ \\
\hline Castlegate* $^{*}$ & $\begin{array}{l}\text { Diagenetic. Very dense } \\
\text { unlocked analogue reservoir } \\
\text { silica sandstone. Sub- } \\
\text { angular, lightly cemented } \\
\text { naturally. }\end{array}$ & $\begin{array}{l}\text { Colorado- } \\
\text { Utah, USA }\end{array}$ & $0.33^{*}$ & & 30.7 & 0.172 & 2.11 & & & $\begin{array}{l}\text { Alvarado, 2007, Alvarado et } \\
\text { al., } 2012 .\end{array}$ \\
\hline
\end{tabular}




\begin{tabular}{|c|c|c|c|c|c|c|c|c|c|c|}
\hline $\begin{array}{l}\text { Fraser River } \\
\text { (FRS) }\end{array}$ & $\begin{array}{l}\text { Clean fine silica sand } \\
\text { interbedded with organic silt. }\end{array}$ & $\begin{array}{l}\text { Fraser } \\
\text { River, } \\
\text { Canada }\end{array}$ & 0.627 & 0.995 & 35 & & & 0.029 & 1.11 & Chillarige et al., 1997. \\
\hline $\begin{array}{l}\text { Longstone } \\
\text { (LS) }\end{array}$ & $\begin{array}{l}\text { Quarried from a location near } \\
\text { Athens. Not marine. }\end{array}$ & Greece & 0.614 & 0.995 & 33 & 0.17 & 1.37 & 0.0072 & 0.893 & $\begin{array}{l}\text { Tsomokos \& Georgiannou, } \\
2010 .\end{array}$ \\
\hline Thanet & $\begin{array}{l}\text { Palaeocene, deposited in a } \\
\text { shallow sea (sublittoral) } \\
\text { environment. Grey silty fine } \\
\text { sands of predominantly silica } \\
\text { mineralogy }(70-85 \%) \text { with } \\
\text { smaller quantities of chert, } \\
\text { pyrite, feldspar, glauconite \& } \\
\text { clay. }\end{array}$ & $\begin{array}{l}\text { London } \\
\text { basin, UK } \\
\text { (upper } \\
\text { stratum) }\end{array}$ & 0.659 & 0.808 & 32 & 0.13 & 1.76 & 0.056 & 1.156 & Ventouras \& Coop, 2009. \\
\hline Stava & $\begin{array}{l}\text { Mine tailing, } 81 \% \text { silica, } 10 \% \\
\text { calcite, } 3 \% \text { fluorite, and } \\
\text { smaller amounts of } \\
\text { illite/mica, K-feldspar and } \\
\text { kaolinite. }\end{array}$ & $\begin{array}{l}\text { Stava } \\
\text { valley/ Italy }\end{array}$ & 0.615 & 1.068 & 35 & 0.139 & 1.70 & 0.0098 & 0.987 & Carrera et al., 2011. \\
\hline Osorio & $\begin{array}{l}\text { Uniformly graded fine silica. } \\
\text { Rounded-sub-rounded. }\end{array}$ & $\begin{array}{l}\text { Near Porto } \\
\text { Alegre- } \\
\text { Southern } \\
\text { Brazil }\end{array}$ & 0.57 & 0.85 & 37 & 0.156 & 1.80 & 0.017 & 0.9 & $\begin{array}{l}\text { Silva Dos Santos et al., } \\
\text { 2010; Heineck et al., } 2005 .\end{array}$ \\
\hline Hostun & Fine angular silica sand & France & 0.656 & 1 & 35.7 & 0.16 & 1.55 & 0.02 & 0.892 & $\begin{array}{l}\text { Schanz \& Vermeer, 1996; } \\
\text { Amat, } 2007 .\end{array}$ \\
\hline Aio sand & Angular silica sand & Japan & 0.582 & 0.958 & 40.6 & 0.133 & & 0.0156 & & Hyodo et al., 1999. \\
\hline Sand & Geological Facts & Location & $\mathbf{e}_{\min }$ & $\mathbf{e}_{\max }$ & $\phi c s$ & $\lambda_{\text {(high) }}$ & $\Gamma_{\text {(high) }}$ & $\lambda_{\text {(low) }}$ & $\Gamma_{\text {(low) }}$ & Ref: \\
\hline \multicolumn{11}{|c|}{ Other mineralogy } \\
\hline $\begin{array}{l}\text { Dogs Bay } \\
\text { Sand (DBS) }\end{array}$ & $\begin{array}{l}\text { Biogenic poorly graded } \\
\text { carbonate sand consisting of } \\
\text { foraminafera \& mollusc } \\
\text { shells. From a dune } \\
\text { environment with highly } \\
\text { angular un-broken particles. }\end{array}$ & $\begin{array}{l}\text { Dog's Bay- } \\
\text { West } \\
\text { Ireland }\end{array}$ & 0.93 & 1.75 & 40 & 0.34 & 3.35 & 0.0083 & 2.74 & Coop \& Lee, 1993. \\
\hline Chiibishi & $\begin{array}{l}\text { Carbonate sand composed of } \\
\text { shells and coral remains. } \\
\mathrm{CaCO}_{3} \text { over } 90 \% \text {. }\end{array}$ & & 0.983 & 1.574 & 43 & 0.19 & 2.20 & 0.073 & 1.668 & $\begin{array}{l}\text { Nakata et al., 1999; Kato et } \\
\text { al., } 2001 .\end{array}$ \\
\hline
\end{tabular}




\begin{tabular}{|c|c|c|c|c|c|c|c|c|c|c|}
\hline Shirasu & $\begin{array}{l}\text { Weathered deposit of } \\
\text { crushable volcanic ash } \\
\text { sediment with a high } \mathrm{C}_{\mathrm{u}} \text {. } \\
\text { Contains } 20-30 \% \text { gravel and } \\
\text { non-plastic fines. }\end{array}$ & $\begin{array}{l}\text { Airagun, } \\
\text { Kagoshima } \\
\text { prefecture, } \\
\text { southern } \\
\text { Kyushu- } \\
\text { Japan }\end{array}$ & 1.027 & 1.551 & 36 & 0.205 & & 0.035 & & $\begin{array}{l}\text { Hyodo et al., 1999; Hira et } \\
\text { al., } 2006 .\end{array}$ \\
\hline Massado & $\begin{array}{l}\text { Moderately weathered } \\
\text { decomposed granite, } \\
\text { crushable residual granite } \\
\text { (silica, feldspar and mica), } \\
\text { with high fines fraction }\end{array}$ & Ube- Japan & 0.81 & 1.353 & & & & & & $\begin{array}{l}\text { Hyodo et al., 1999; } \\
\text { Yoshimoto et al., } 2012 .\end{array}$ \\
\hline Langjokull & $\begin{array}{l}\text { A lodgement basaltic till } \\
\text { recovered from a pro-glacial } \\
\text { site at the retreated margin } \\
\text { of Vestari-Hagafellsjökull in } \\
\text { the Langjökull ice cap. }\end{array}$ & $\begin{array}{l}\text { Langjökull } \\
\text { glacier } \\
\text { Iceland }\end{array}$ & 0.4 & 0.58 & 35 & 0.037 & 0.664 & & & Altuhafi et al., 2010. \\
\hline $\begin{array}{l}\text { Crushed } \\
\text { glass beads }\end{array}$ & & & & & 35.2 & 0.168 & 1.705 & 0.006 & & Cavarretta, 2009. \\
\hline glass beads & & & 0.542 & 0.72 & 21 & 0.268 & & 0.039 & 0.807 & Cho et al., 2006. \\
\hline
\end{tabular}

- Void ratio reported for undisturbed diagenetic sediment * reconstituted material is used for this study. 
Table 2. Grading, shape and surface roughness of the sands.

\begin{tabular}{|c|c|c|c|c|c|c|c|c|c|}
\hline \multirow[t]{2}{*}{ Sand } & \multicolumn{2}{|c|}{ Grading Properties } & \multicolumn{3}{|c|}{ Shape Properties } & \multicolumn{2}{|c|}{ Roughness } & \multirow[t]{2}{*}{ SAGI } & \multirow{2}{*}{$\begin{array}{l}\text { Angularity } \\
\text { class }\end{array}$} \\
\hline & $D_{50,} \mu \mathrm{m}$ & $\mathrm{C}_{\mathrm{u}}$ & AR & $C_{x}$ & $\mathbf{S}$ & $\mathrm{S}_{\mathrm{a}}, \mathrm{nm}$ & $\mathbf{s}_{\mathbf{q}}, \mathrm{nm}$ & & \\
\hline Badger sand & 882 & 1.2 & 0.81 & 0.98 & 0.930 & & & 5.5 & Rounded \\
\hline Ottawa & 800 & 1.21 & 0.797 & 0.974 & 0.918 & 75.9 & 109 & 7.0 & Rounded \\
\hline Albany sand & 300 & 2.22 & 0.760 & 0.949 & 0.903 & & & 9.7 & Rounded \\
\hline M31 & 340 & 1.51 & 0.755 & 0.946 & 0.899 & 94 & 140.2 & 10.2 & Sub-rounded \\
\hline Monterey & 360 & 1.5 & 0.749 & 0.954 & 0.891 & & & 10.9 & Sub-rounded \\
\hline Nevada & 164 & 1.41 & 0.772 & 0.927 & 0.909 & & & 10.8 & Sub-rounded \\
\hline Ticino & 612 & 1.47 & 0.732 & 0.951 & 0.879 & & & 11.3 & Sub-angular \\
\hline HRS & 325 & 1.59 & 0.705 & 0.933 & 0.892 & 88.5 & 133 & 11.3 & Sub-angular \\
\hline Greensand & 266 & 1.74 & 0.753 & 0.935 & 0.894 & \begin{tabular}{|l|}
152.0 \\
\end{tabular} & 200.0 & 11.3 & Sub-angular \\
\hline Toyoura & 246 & 1.37 & 0.743 & 0.934 & 0.894 & \begin{tabular}{|l|}
230.2 \\
\end{tabular} & 352.6 & 11.3 & Sub-angular \\
\hline FBS-NE34 & 246 & 1.37 & 0.731 & 0.9332 & 0.889 & 111.4 & 162.4 & 11.7 & Sub-angular \\
\hline Saltwash & 152 & 2.35 & 0.745 & 0.921 & 0.900 & 265.6 & 387.7 & 11.8 & Sub-angular \\
\hline Castlegate & 294 & 2.37 & 0.762 & 0.925 & 0.897 & 294.5 & 410.6 & 11.8 & Sub-angular \\
\hline FRS & 309 & 1.74 & 0.723 & 0.939 & 0.882 & & & 11.8 & Sub-angular \\
\hline Longstone & 191 & 1.42 & 0.724 & 0.921 & 0.892 & 144.7 & 221.6 & 12.2 & Angular \\
\hline Thanet & 153 & 2.62 & 0.742 & 0.911 & 0.900 & & & 12.4 & Angular \\
\hline Stava & 181 & 2.11 & 0.729 & 0.925 & 0.881 & 242.5 & 355.8 & 12.9 & Angular \\
\hline Osorio & 181 & 2.11 & 0.699 & 0.926 & 0.876 & 251.9 & 385.96 & 13.0 & Angular \\
\hline Hostun & 380 & 1.54 & 0.723 & 0.935 & 0.869 & & & 13.1 & Angular \\
\hline Aio sand & 400 & 2.74 & 0.718 & 0.947 & 0.857 & & & 13.2 & Angular \\
\hline DBS & 271 & 2.56 & 0.664 & 0.898 & 0.828 & & & 18.5 & Angular \\
\hline Chiibishi & 613 & 2.40 & 0.664 & 0.921 & 0.859 & & & 14.5 & Angular \\
\hline Shirasu & 370 & 3.59 & 0.706 & 0.903 & 0.872 & & & 14.9 & Angular \\
\hline Massado & 509 & 1.10 & 0.712 & 0.916 & 0.876 & & & 13.8 & Angular \\
\hline Langjökull & 100 & 4.84 & 0.751 & 0.942 & 0.882 & 210.8 & 312.9 & 11.8 & Sub-angular \\
\hline glass beads & 213 & 1.22 & 0.936 & 0.947 & 0.945 & & & 7.5 & Rounded \\
\hline Crushed GB & 186 & 2.50 & 0.679 & 0.960 & 0.856 & & & 12.2 & Angular \\
\hline
\end{tabular}


Table 3. Values of $\mathrm{C}_{\mathrm{g}}$, $\mathrm{e}_{\mathrm{g}}$ and $\mathrm{n}$ obtained from previous studies

\begin{tabular}{|l|l|l|l|l|}
\hline Soil & $\mathrm{C}_{\mathrm{g}}$ & $\mathrm{e}_{\mathrm{g}}$ & $\mathrm{n}$ & Ref \\
\hline Monterey (0) & 326 & 2.97 & 0.50 & Bolton 1986 \\
\hline Ticino & 647 & 2.27 & 0.43 & $\begin{array}{l}\text { Lo Presti et al., } \\
1997 \text { \& Salgado } \\
\text { et al. 2000 }\end{array}$ \\
\hline Toyoura & 900 & 2.17 & 0.40 & $\begin{array}{l}\text { Lo Presti et al., } \\
1997\end{array}$ \\
\hline Ottawa (round) & 612 & 2.17 & 0.44 & $\begin{array}{l}\text { Salgado et al., } \\
\text { 2000 }\end{array}$ \\
\hline FBS & 200 & 2.17 & 0.47 & $\begin{array}{l}\text { Delfosse-Ribaya } \\
\text { et al. 2004 }\end{array}$ \\
\hline FRS & 14.89 & 2.0 & 0.42 & $\begin{array}{l}\text { Chillariage et al., } \\
1997\end{array}$ \\
\hline Nevada $^{*}$ & 636 & 2.17 & 0.491 & ----------- \\
\hline
\end{tabular}

- Values reported here for $p_{a}=100 \mathrm{kPa}$

- $\quad{ }^{*}$ Calculated in this study from data by Gibson 1996

Table 4. The applicability of various void ratio functions and pressure term exponents to the experimental results of selected sands in the database.

\begin{tabular}{|c|c|c|c|c|c|c|}
\hline \multirow[t]{2}{*}{ Soil } & \multirow{2}{*}{$\begin{array}{l}\text { Testing } \\
\text { Method }\end{array}$} & \multirow{2}{*}{$\begin{array}{l}\text { Reference } \\
\text { for data }\end{array}$} & \multicolumn{3}{|c|}{ Correlation $\mathrm{R}^{2}$} & \multirow{2}{*}{$\begin{array}{l}\text { Void ratio } \\
\text { range }\end{array}$} \\
\hline & & & $\begin{array}{l}\text { Hardin \& } \\
\text { Richart, } \\
1963\end{array}$ & $\begin{array}{l}\text { Lo Presti } \\
\text { et al., } \\
1997\end{array}$ & $\begin{array}{l}\text { Biarez \& } \\
\text { Hicher, } \\
1994\end{array}$ & \\
\hline Ottawa & $\begin{array}{l}\text { Bender } \\
\text { element }\end{array}$ & $\begin{array}{l}\text { Salgado et } \\
\text { al., } 2000\end{array}$ & 0.929 & 0.934 & 0.925 & $0.58-0.61$ \\
\hline Nevada & $\begin{array}{l}\text { Resonant } \\
\text { column }\end{array}$ & $\begin{array}{l}\text { Gibson } \\
1996\end{array}$ & 0.997 & 0.996 & 0.886 & $\begin{array}{l}0.661- \\
0.736 \\
\end{array}$ \\
\hline FRS & $\begin{array}{l}\text { Bender } \\
\text { element }\end{array}$ & $\begin{array}{l}\text { Chillariage } \\
\text { et al., } 1997\end{array}$ & $0.893^{*}$ & 0.867 & 0.925 & $0.79-1.11$ \\
\hline Toyoura & $\begin{array}{l}\text { Resonant } \\
\text { column }\end{array}$ & $\begin{array}{l}\text { Youn et al., } \\
2008\end{array}$ & 0.991 & 0.977 & 0.965 & $0.7-0.81$ \\
\hline
\end{tabular}


Table 5. Elastic shear stiffness data of the sands.

\begin{tabular}{|c|c|c|c|c|c|c|}
\hline Sand & Reference & \begin{tabular}{|l} 
Pressure \\
range \\
considered, \\
$\mathrm{kPa}$ \\
\end{tabular} & $\begin{array}{l}\mathrm{C}_{\mathrm{g}} \\
\mathrm{X} 10^{3}\end{array}$ & $\mathbf{n}$ & $\begin{array}{l}G_{0}^{\prime 100} \\
\text { MPa }\end{array}$ & Method \\
\hline Ottawa & $\begin{array}{l}\text { Salgado et } \\
\text { al., } 2000\end{array}$ & $50-500$ & 4.12 & 0.51 & 43.7 & $\begin{array}{l}\text { Bender } \\
\text { Element }\end{array}$ \\
\hline Badger & Rouse 2003 & & 4.89 & 0.47 & 42.6 & $\begin{array}{l}\text { Bender } \\
\text { Element }\end{array}$ \\
\hline M31 & This study & $75-300$ & 6.72 & 0.51 & 71.8 & \begin{tabular}{|l|} 
Torsional \\
Shear
\end{tabular} \\
\hline Monterey 0 & $\begin{array}{l}\text { Saxena \& } \\
\text { Reddy, } 1989\end{array}$ & $50-600$ & 3.70 & 0.51 & 39.3 & $\begin{array}{l}\text { Resonant } \\
\text { Column }\end{array}$ \\
\hline \multirow[t]{2}{*}{ Nevada } & $\begin{array}{l}\text { Yun \& } \\
\text { Santamarina, } \\
2005\end{array}$ & -660 & 2.49 & 0.64 & 47.4 & \begin{tabular}{|l} 
Bender \\
Element
\end{tabular} \\
\hline & Gibson, 1996 & $40-320$ & 5.00 & 0.50 & 50.4 & $\begin{array}{l}\text { Resonant } \\
\text { Column }\end{array}$ \\
\hline Ticino & $\begin{array}{l}\text { Bellotti et al., } \\
1996\end{array}$ & $50-300$ & 7.03 & 0.48 & 65.2 & $\begin{array}{l}\text { Bender } \\
\text { Element }\end{array}$ \\
\hline HRS & $\begin{array}{l}\text { Jovicic \& } \\
\text { Coop, } 1997\end{array}$ & $50-3750$ & 5.37 & 0.52 & 58.8 & $\begin{array}{l}\text { Bender } \\
\text { Element }\end{array}$ \\
\hline Greensand & $\begin{array}{l}\text { Cuccovillo \& } \\
\text { Coop, } 1997\end{array}$ & $300-850$ & 1.75 & 0.62 & 30.3 & \begin{tabular}{|l|} 
Triaxial \\
Probes \\
\end{tabular} \\
\hline Toyoura & $\begin{array}{l}\text { Youn et al., } \\
2008\end{array}$ & $50-420$ & 6.97 & 0.48 & 62.3 & \begin{tabular}{|l|} 
BE+ RC+ \\
Torsion
\end{tabular} \\
\hline \multirow[t]{2}{*}{ FBS } & $\begin{array}{l}\text { Delfosse- } \\
\text { Ribay et al., } \\
2004\end{array}$ & -300 & \multirow[t]{2}{*}{4.49} & \multirow[t]{2}{*}{0.53} & \multirow[t]{2}{*}{51.6} & \begin{tabular}{|l} 
Resonant \\
Column
\end{tabular} \\
\hline & $\begin{array}{lr}\text { Dano } \quad \& \\
\text { Hitcher } & 2003 \\
\end{array}$ & $100-500$ & & & & \begin{tabular}{|l|} 
Bender \\
Element
\end{tabular} \\
\hline Saltwash & $\begin{array}{l}\text { Alvarado et } \\
\text { al. 2012 }\end{array}$ & -1000 & 0.86 & 0.67 & 18.8 & \begin{tabular}{|l|} 
Triaxial \\
Probes
\end{tabular} \\
\hline Thanet & $\begin{array}{l}\text { Ventouras \& } \\
\text { Coop } 2009 \\
\end{array}$ & $180-1000$ & 6.23 & 0.47 & 54.0 & $\begin{array}{l}\text { Bender } \\
\text { Element }\end{array}$ \\
\hline Osorio & $\begin{array}{l}\text { Consoli et al. } \\
2005\end{array}$ & $150-950$ & 12.34 & 0.44 & 124.0 & $\begin{array}{l}\text { Bender } \\
\text { Element }\end{array}$ \\
\hline Huston & Amat 2007 & $30-150$ & 5.04 & 0.54 & 83.6 & $\begin{array}{l}\text { Bender } \\
\text { Element }\end{array}$ \\
\hline Longstone & This study & $100-300$ & 10.24 & 0.45 & 82.8 & $\begin{array}{l}\text { Torsional } \\
\text { Shear }\end{array}$ \\
\hline FRS & $\begin{array}{l}\text { Chillariage et } \\
\text { al, } 1997\end{array}$ & $150-450$ & 2.25 & 0.61 & 36.9 & $\begin{array}{l}\text { Bender } \\
\text { Element }\end{array}$ \\
\hline DBS & $\begin{array}{l}\text { Jovicic \& } \\
\text { Coop } 1997\end{array}$ & -4000 & 11.32 & 0.58 & 167.3 & \begin{tabular}{|l} 
Bender \\
Element \\
\end{tabular} \\
\hline GB & $\begin{array}{l}\text { Kuwano } \\
1999\end{array}$ & $40-200$ & 4.14 & 0.48 & 38.4 & $\begin{array}{l}\text { Bender } \\
\text { Element }\end{array}$ \\
\hline
\end{tabular}

*Assuming RD= 0.67 
Table 6. Statistical comparisons of SAGI with shape identification methods available in literature.

\begin{tabular}{|l|l|l|l|}
\hline Method & Reference & Value reported by & $\mathrm{R}^{2}$ \\
\hline Roundness (C\&S) & Crumbein \& Sloss,1963 & Cho et al., 2006 & 0.8867 \\
\hline Degree of Angularity & Lees, 1964 & Duttine \& Tatsuoka, 2009 & 0.8899 \\
\hline Roundness & Kato et al., 2001 & Yoshimoto et al., 2012 & 0.5228 \\
\hline
\end{tabular}




$$
\begin{aligned}
& 1 \\
& 2
\end{aligned}
$$

